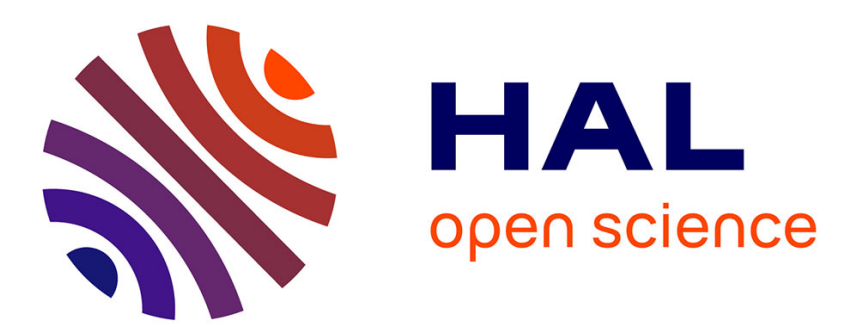

\title{
Thermal constraints on the emplacement rate of e large intrusive complex: the Manaslu Leucogranite, Nepal Himalaya.
}

\author{
Catherine Annen, Bruno Scaillet, R.S.J. Sparks
}

\section{- To cite this version:}

Catherine Annen, Bruno Scaillet, R.S.J. Sparks. Thermal constraints on the emplacement rate of e large intrusive complex: the Manaslu Leucogranite, Nepal Himalaya.. Journal of Petrology, 2006, 47, pp.71-95. 10.1093/petrology/egi068 . hal-00022869

\section{HAL Id: hal-00022869}

\section{https://hal-insu.archives-ouvertes.fr/hal-00022869}

Submitted on 31 May 2006

HAL is a multi-disciplinary open access archive for the deposit and dissemination of scientific research documents, whether they are published or not. The documents may come from teaching and research institutions in France or abroad, or from public or private research centers.
L'archive ouverte pluridisciplinaire HAL, est destinée au dépôt et à la diffusion de documents scientifiques de niveau recherche, publiés ou non, émanant des établissements d'enseignement et de recherche français ou étrangers, des laboratoires publics ou privés. 


\title{
Thermal Constraints on the Emplacement Rate of a Large Intrusive Complex: The Manaslu Leucogranite, Nepal Himalaya.
}

\author{
C. ANNEN ${ }^{*}$, B. SCAILLET2 AND R. S. J. SPARKS 3
}

\begin{abstract}
1 SECTION DES SCIENCES DE LA TERRE, UNIVERSITE DE GENEVE, 13 RUE DES MARAICHERS, 1205 GENEVE, SWITZERLAND

2 INSTITUT DES SCIENCES DE LA TERRE D'ORLEANS, UMR 6113 CNRS-UO, 1A RUE DE LA FEROLLERIE 45071 ORLE'ANS CEDEX 2, FRANCE

3 DEPARTMENT OF EARTH SCIENCES, UNIVERSITY OF BRISTOL, WILLS MEMORIAL BUILDING, QUEENS ROAD, BRISTOL BS8 1RJ, UK
\end{abstract}

KEY WORDS : granite emplacement; heat transfer modelling; High Himalayan Leucogranite; Manaslu; thermal aureole

The emplacement of the Manaslu leucogranite body (Nepal, Himalaya) has been modelled as the accretion of successive sills. The leucogranite is characterized by isotopic heterogeneities suggesting limited magma convection, and by a thin $(<100 \mathrm{~m})$ upper thermal aureole. These characteristics were used to constrain the maximum magma emplacement rate. Models were tested with sills injected regularly over the whole duration of emplacement and with two emplacement sequences separated by a repose period. Additionally, the hypothesis of a tectonic top contact, with unroofing limiting heat transfer during magma emplacement, was evaluated. In this latter case, the upper limit for the emplacement rate was estimated at 3-4 mm/year (or 1-5 Myr for $5 \mathrm{~km}$ of granite). Geological and thermobarometric data, however, argue against a major role of fault activity in magma cooling during the leucogranite emplacement. The best model in agreement with available geochronological data suggests an emplacement rate of 1 $\mathrm{mm} /$ year for a relatively shallow level of emplacement (granite top at $10 \mathrm{~km}$ ), uninterrupted by a long repose period. The thermal aureole temperature and thickness, and the isotopic heterogeneities within the leucogranite, can be explained by the accretion of 20-60 m thick sills intruded every 20 000-60 000 years over a period of $5 \mathrm{Myr}$. Under such conditions, the thermal effects of granite intrusion on the underlying rocks appear limited and cannot be invoked as a cause for the formation of migmatites. 


\section{INTRODUCTION}

The melting of continental crust can be achieved via two fundamental mechanisms: either by advective heating resulting from basalt underplating or intrusion (Huppert \& Sparks, 1988; Bergantz, 1989; Raia \& Spera, 1997) or via thickening of crust rich in heat-producing elements (England \& Thompson, 1984), assisted or not by shear heating (Le Fort, 1975; England et al., 1992; Harrison et al., 1998) or isothermal decompression (Harris \& Massey, 1994). The Himalaya range is a collisional belt characterized by the production of crustal melts without the involvement of basalt (Le Fort et al., 1987). Thus, it is a place where models belonging to the second category can be investigated.

Study of the High and North Himalayan Leucogranites (HHL and NHL) has been pivotal for understanding the structural and thermal evolution of thickened crust in collisional settings. The HHL are generally located on top of a high-grade metamorphic unit-the Precambrian Higher Himalayan Crystallines $(\mathrm{HHC})$-which forms the backbone of the range, and below a thick Paleozoic to Mesozoic sedimentary sequence, termed the Tethyan Sedimentary Series (TSS). The HHC is truncated at its base by the Main Central Thrust (MCT), a $10 \mathrm{~km}$ thick shear zone that has accommodated part of the Himalayan Miocene-Pliocene shortening. The top of the HHC is defined by the South Tibetan Detachment (STD), a low-dipping extensional, ductile to brittle crustal-scale shear zone that is believed to have been episodically active since the Miocene, perhaps in response to gravitational instability of the Himalayan topographic front (Burg et al., 1984; Royden \& Burchfiel, 1985). The HHC is believed to have been extruded by simultaneous motion along the MCT and STD (Hodges et al., 1992). The HHL may be related to the development of either the MCT or STD and their dating has been used to constrain the age of fault movement (Guillot et al., 1994; Coleman, 1998; Dezes et al., 1999; Murphy \& Harrison, 1999). Geochronological data show that most of the HHL were produced in the time interval 24-19 Ma (Harrison et al., 1999b). The onset of the India-Tibet collision is dated at_55Ma in the west of the range (Rowley, 1996; Guillot et al., 2003), with a probable younging eastward because of the obliquity of convergence between India and Tibet. The time lag of 20-30 Myr between crustal thrust stacking and crustal melting is significantly shorter than results from numerical simulations of the thermal evolution of the thickened crust, which predict that melting occurs some $50 \mathrm{Myr}$ after thickening (England \& Thompson, 1984). Therefore, modelling studies on the thermal evolution of the Himalayan orogenic belt have looked for either additional sources of heat, or alternative mechanisms of crustal melting, to explain the time lag and its relationship to the tectonometamorphic evolution of the orogen, in particular the wellknown inverted metamorphic gradient that affects the HHC (Molnar et al., 1983; Pinet \& Jaupart, 1987; England et al., 1992; Henry et al., 1997; Harrison et al., 1998, 1999a). Alternative mechanisms include shear heating (England et al., 1992; Harrison et al., 1998), accretion of radiogenic crustal layers (Huerta et al., 1999; Guillot \& Allemand, 2002), thermal conductivity contrast between the crystalline basement and its sedimentary cover (Pinet \& Jaupart, 1987), large-scale fluid infiltration that lowers the melting point of overthrust terranes (Le Fort, 1975), slab break-off during collision (Kohn \& Parkinson, 2002) and fast decompression of hot metamorphic rocks (Harris \& Massey, 1994). Although differing in many respects, most recent models propose that both compressional and extensional faults exert a central role in the orographic development of the orogen (Harris \& Massey, 1994; Grujic et al., 1996; Nelson et al., 1996; Beaumont 
et al., 2001; Vannay \& Grasemann, 2001). Recent studies suggest that exhumation of $\mathrm{HHC}$ results from the competing effects of the ductile extrusion of a crustal channel (HHC), bounded by low-angle normal (STD) and thrust (MCT) faults. Focused surface denudation (erosion) is localized at the southern edge of the Tibetan Plateau (i.e. the Himalaya). This hypothesis requires that both MCT and SDT detachments were simultaneously active. Several geophysical surveys have indicated the presence of partial melt in the Tibetan middle crust, immediately north of the Himayalan range (Pham et al., 1986; Brown et al., 1996; Nelson et al., 1996), which has led to the suggestion that the Himalaya range could correspond to the southward extrusion of the partially molten crust underlying southern Tibet, and that contemporary melting beneath south Tibet could be the continuation of the dynamical processes that formed the HHL during the Miocene (Wu et al., 1998; Hodges et al., 2001; Beaumont et al., 2004). This channel flow model seeks to unify geological, geochronological and geophysical observations gathered in the Himalayan-Tibetan area (Hodges et al., 2001; Beaumont et al., 2004). Interest in the tectonic exhumation concept has also been triggered by the suggestion that production of high reliefs, following the India-Tibet collision, could have affected global climate (Raymo \& Ruddiman, 1992). Abrupt changes in world seawater chemistry in the Miocene (Edmond, 1992; Harris et al., 1995), as well as the sedimentary record of the Bengal Fan (France-Lanord et al., 1993), have been explained by Miocene land exposure and subsequent erosion of $\mathrm{HHC}$ and $\mathrm{HHL}$ rocks. Because Himalayan metamorphism and magmatism are essentially Miocene in age, their exhumation during the Miocene requires a fast mechanism of rock uplift. Tectonic unroofing of thermally weakened (i.e. partially melted) crust is commonly advocated (Hodges et al., 1998; Searle \& Godin, 2003). However, the mechanisms leading to crustal melting, as well as the role of partial melt in the development of the Himalayan orogen, are still controversial (Harrison et al., 1999a). It is still unclear to what extent crustal melting is related to crustal faults and, if so, whether it is the cause or the consequence of crustal-scale compressional (MCT) or extensional (STD) faulting. Both the orogenic wedge (e.g. Harris \& Massey, 1994) and channel flow (e.g. Beaumont et al., 2004) models require that motions on both the MCT and STD were broadly contemporaneous with the formation of the HHL. Although available timing constraints are consistent with this idea, it is not the only possibility (Murphy \& Harrison, 1999). Models that do not invoke normal faulting can also reproduce the principal tectono-metamorphic and geochronological constraints of the Himalaya (Harrison et al., 1998). In this study, we model the thermal evolution of individual leucogranite bodies to constrain emplacement rates of the HHL plutons. From inferred emplacement rates, the residence time of anatectic melts in their source regions can be constrained. The study also sheds light on the potential role of extensional faulting on crustal magmatism, as coeval STD slip and $\mathrm{HHL}$ emplacement should affect the cooling regime of the HHL. Our model only concerns the period of pluton emplacement. We combine these results with fluid dynamic considerations to constrain the conditions under which HHL cooling could be achieved in a purely conductive regime. The geochemical characteristics of the HHL suggest emplacement with no large-scale convection within the magma bodies (Deniel et al., 1987). Modelling the thermal evolution of the HHL plutons is relevant to the following Himalayan issues. (1) We explore heat advection within the Himalayan crust to test whether the increase in degree of migmatization observed up-section in the $\mathrm{HHC}$ (i.e. the so-called inverse 
metamorphism) could be a result of $\mathrm{HHL}$ intrusion, as has been proposed in Bhutan by Davidson et al. (1997).

(2) The HHL have been alternatively interpreted as plutons emplaced in situ close to their level of production (Visona \& Lombardo, 2002), and as intrusive bodies in cold upper crust detached from their source, with vertical transport distances of $\sim 8-10 \mathrm{~km}$ (Copeland et al., 1990; Inger \& Harris, 1992; Guillot et al., 1995b; Scaillet et al., 1996; Walker et al., 1999). The level of pluton intrusion has a major impact on its subsequent thermal evolution (Davidson et al., 1992), and our modelling results aim to distinguish between these hypotheses.

(3) Our model provides a framework for interpreting geochronological data for the HHL, which have been difficult to date accurately. Progress has been made with ion probe studies (Harrison et al., 1999b). However, the accessory minerals used for dating can be inherited (Copeland et al., 1988), so even these methods are not straightforward (Harrison et al., 1999b).

\section{General modelling approach}

Our thermal models place constraints on the emplacement of granite intrusions. We apply the model results to the Manaslu leucogranite, the best known of the HHL (Le Fort et al., 1987; France-Lanord et al., 1988; Guillot et al., 1995a). As a result of the highly dissected nature of the Himalaya range, field observations provide a continuous record of the nature of the host rocks of the HHL, both above and beneath the intrusions, down to levels where crustal melting occurred. These data, combined with the wealth of geological, petrological and geochemical data summarized below, place tight constraints on key parameters that affect the thermal evolution of the cooling plutons, including the $\mathrm{P}-\mathrm{T}-\mathrm{H}_{2} \mathrm{O}$ conditions of the magma and its surroundings during injection and the country rock properties.

Geological and geophysical data indicate that many granitic plutons, including the HHL, are tabular, lowaspect ratio bodies fed by thin vertical conduits (Le Fort, 1981; Scaillet et al., 1995a; McCaffrey \& Petford, 1997; Cruden, 1998; Searle, 1999; Petford et al., 2000; Haederle \& Atherton, 2002). Field observations combined with detailed isotopic studies suggest that the $\mathrm{HHL}$ are an amalgamation of numerous accreted intrusions (Deniel et al., 1987), as has been inferred for many other plutons (Evans et al., 1993; Wiebe \& Collins, 1998; Glazner et al., 2004). The basic modelling concept is the successive emplacement of numerous thin sills, which grow into a large granite intrusion. The intrusions are sufficiently wide in comparison to their thickness that a 1-D model can be justified. We have modelled the heat transfer between the growing intrusion and its country rocks. Our objective is to constrain the thermal regime that leads to the emplacement of a lensoid igneous body several kilometres wide in the upper crust that, once solidified, is characterized by two critical features: (1) a strong Sr-isotopic heterogeneity that precludes wholesale convection causing magma mixing and homogenization; (2) a thin, no more than 100m thick, top contact aureole. 
THE MANASLU LEUCOGRANITE AND ITS HOST ROCKS Bottom and top host rocks

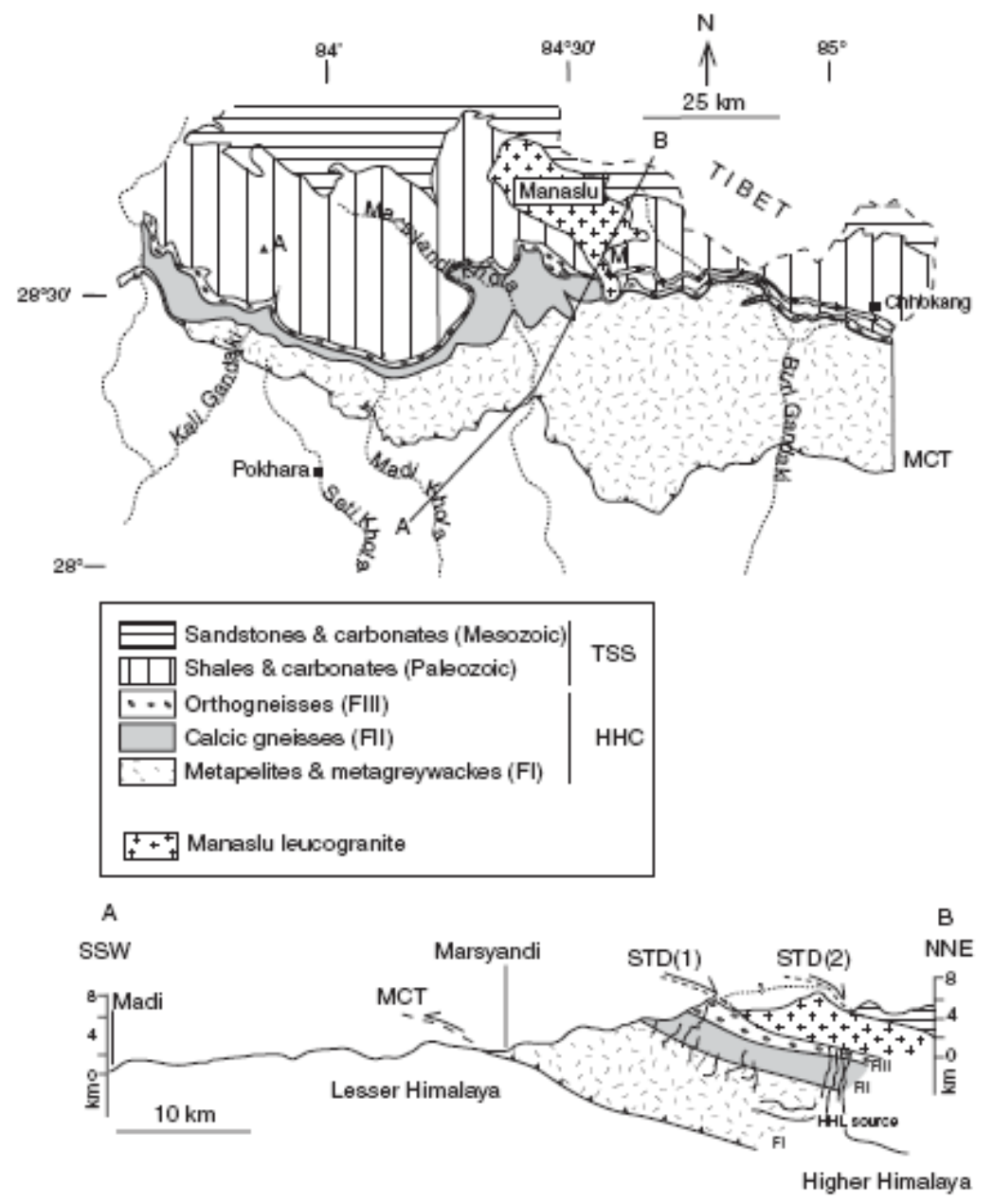

Fig. 1. Generalized geological map of the Manaslu area in central Nepal, after Colchen et al. (1986), and NE-SW cross-section of the High Himalayan range showing the main geological units discussed in the text (adapted from Colchen et al., 1986). Only the main lithological units are shown, together with the position of the Main Central Thrust (MCT). On the map, other tectonic contacts (STD) are omitted for clarity. On the cross-section, two positions for the South Tibetan Detachment (STD) are shown: STD (1) is according to Guillot et al. (1993) (i.e. below the pluton); STD(2) is according to Searle \& Godin (2003) (above the pluton). M, Manaslu peak; A, Annapurna peak.

The Manaslu pluton is exposed in central Nepal, covers an area of $400 \mathrm{~km} 2$ and has an estimated volume of $3000 \mathrm{~km} 3$ (Le Fort et al., 1987). It is a laccolithic-shaped body with a thickness of up to $5-6 \mathrm{~km}$ and a lateral extent of $30-40 \mathrm{~km}$ (Fig. 1). The Manaslu pluton is located on top of the $\mathrm{HHC}$, which is here divided into three sub-units of variable thickness: FI, FII and FIII (Colchen et al., 1986). The basal unit, FI (thickness 2-10 km), is made of alternating metapelitic and metagreywacke gneisses metamorphosed within kyanite (bottom) to sillimanite (top) grades. FI is truncated at its base by the Main Central Thrust (Fig. 1). Migmatization is prominent in F1 and increases upsection 
(Barbey et al., 1996; Coleman, 1998). U-Pb geochronology on monazite and zircon gives migmatization ages of 18-22_5Ma for FI migmatites (Hodges et al., 1996; Coleman, 1998). The FI unit is overlain by the FII unit of calcic gneisses; this is up to 3.5 $\mathrm{km}$ thick but displays strong lateral variations in thickness (Fig. 1). The FIII unit is made of variably migmatized porphyritic orthogneisses, $1 \mathrm{~km}$ thick, that are interpreted as the metamorphosed equivalent of Cambro-Ordovician metaluminous to weakly peraluminous granites occurring in the Lesser Himalaya (Le Fort, 1986). U-Pb dating of monazite suggests that the age of migmatization of the FIII orthogneisses is older than the FI migmatites, at around $36 \mathrm{Ma}$, or early Oligocene (Hodges et al., 1996; Coleman, 1998). Themobarometric studies have shown that peak metamorphic pressures at the base of the $\mathrm{HHC}$ (close to the MCT) are in the range 8-10 kbar, and decrease regularly upsection down to about $5 \mathrm{kbar}$ at the top of the HHC (Pecher, 1989; Coleman \& Hodges, 1998; Guillot, 1999; Macfarlane, 1999). Peak temperature varies between 580 and $700^{\circ} \mathrm{C}$ within the $\mathrm{HHC}$ in this area (Pecher, 1989; Coleman \& Hodges, 1998; Guillot, 1999; Macfarlane, 1999).

Temperatures up to $800^{\circ} \mathrm{C}$ have been estimated along other transects, such as in the Langtang section, some $75 \mathrm{~km}$ west of Manaslu (Inger \& Harris, 1992), whereas other studies suggest a maximum temperature of $750^{\circ} \mathrm{C}$ even in rocks that are partially melted (Ayres \& Harris, 1997; Harris et al., 2004). However, these thermobarometric constraints provide only minimum temperatures, as the metamorphic grade increases northward. Thus, peak temperatures reached in the source region of the $\mathrm{HHL}$, which is presumably located beneath the HHL or further north, must be somewhat higher than those recorded in more distal (i.e. southward) sections of the HHC thrust sheet. Overlying the HHC is the Tethyan (or Tibetan) sedimentary series (TSS), which forms a near-continuous, weakly to non-metamorphosed, Paleozoic to Mesozoic (up to the Cretaceous) sequence, in which MgO-poor limestones dominate over sandstones and shales (Colchen et al., 1986). The top of the granite is in contact with progressively higher stratigraphic units westward, from lower Paleozoic levels up to Upper Triassic shales in the middle part of the lens (Fig. 1). The restored thickness of the sedimentary sequence in the area of the Manaslu pluton reaches $11 \mathrm{~km}$ (Colchen et al., 1986). However, these thermobarometric constraints provide only minimum temperatures, as the metamorphic grade increases northward. Thus, peak temperatures reached in the source region of the $\mathrm{HHL}$, which is presumably located beneath the HHL or further north, must be somewhat higher than those recorded in more distal (i.e. southward) sections of the $\mathrm{HHC}$ thrust sheet. Overlying the HHC is the Tethyan (or Tibetan) sedimentary series (TSS), which forms a near-continuous, weakly to non-metamorphosed, Paleozoic to Mesozoic (up to the Cretaceous) sequence, in which $\mathrm{MgO}$-poor limestones dominate over sandstones and shales (Colchen et al., 1986). The top of the granite is in contact with progressively higher stratigraphic units westward, from lower Paleozoic levels up to Upper Triassic shales in the middle part of the lens (Fig. 1). The restored thickness of the sedimentary sequence in the area of the Manaslu pluton reaches $11 \mathrm{~km}$ (Colchen et al., 1986). However, Tertiary folding or nappe emplacement prior to granite intrusion is believed to have significantly increased the overburden depth at the time of granite emplacement (Guillot et al., 1995a). 


\section{Top contact}

The exact location of the STD is contentious in the Manaslu area (Coleman, 1996; Searle \& Godin, 2003). Some workers (Caby et al., 1983; Pecher, 1989, 1991; Coleman, 1998) consider that the STD lies structurally below the Manaslu pluton, which has a top intrusive contact, whereas others (Searle \& Godin, 2003) consider that the STD lies above the granite, as most often observed, and view the top contact of the granite as a tectonic one. For Guillot and collaborators (Guillot, 1993; Guillot et al., 1993, 1995a), the normal shearing observed at the Manaslu top contact is local and related to the ballooning effect of the intrusion process. Given the importance of this contact for the purpose of thermal modelling, we review the observations pertinent to these alternative interpretations. Le Fort (1981), Colchen et al. (1986) and Guillot et al. (1993, 1995a) reported that the top of the pluton develops a thin metamorphic aureole whose thickness depends on the lithology of the local host rocks. At limestone contacts, the aureole only extends $2-3 \mathrm{~m}$ and is marked by clusters of radiating wollastonite (Colchen et al., 1986). At sandstone or shale contacts, the aureole is $30-50 \mathrm{~m}$ thick, and the sedimentary rocks are transformed into muscovite-garnet quartzite and biotite-muscovite-garnet-staurolite micaschists, respectively (Colchen et al., 1986). Thermobarometric studies of the contact metamorphic conditions yielded P-T conditions of $3-4 \mathrm{kbar} / 550 \pm 40^{\circ} \mathrm{C}$ for the top of the pluton and $5-6 \mathrm{kbar} / 580 \pm 40^{\circ} \mathrm{C}$ for the base, in agreement with P-T conditions estimated for the top part of the HHC (Guillot, 1999; Macfarlane, 1999). The difference in barometric estimates between the top and the bottom of the pluton is in good agreement with the lithostatic pressure difference of $\sim 2 \mathrm{kbar}$, corresponding to the structural thickness of the pluton of 5-6 km (Guillot et al., 1995a). In addition, Ar-Ar ages of minerals in the top aureole (Guillot et al., 1994) are similar to the ages of the nearby leucogranite (Copeland et al., 1990). However, Searle \& Godin (2003), working on the northwestern part of the Manaslu area, observed a $400 \mathrm{~m}$ thick shear zone of high-strain mylonites structurally above the pluton, with the upper part displaced to the north. This shear zone is reported to wrap around the northern contact of the pluton, although Searle \& Godin (2003) explored only three valley transects west of the pluton, and extrapolated the shear zone eastward to the area in which Guillot et al. (1995a) worked. We have no reasons to dismiss the general structural interpretation of Searle \& Godin (2003). However, the field and petrological observations of the topmost contact by Guillot et al. (1993, 1995a) cannot be discounted either: in particular, the very thin aureole described in the limestone layers, the presence of host rock xenoliths in the granite (see photo 54 of Colchen et al., 1986), and the age correspondence between the leucogranite and its host rock all suggest that in this area, the intrusive relationship of the granite has been locally preserved and that the P-T conditions derived by Guillot et al. (1995a, 1995b) reflect the conditions of aureole metamorphism. In the eastern area, where the contact aureole has been studied, the STD does not occur at the granite contact, suggesting that the tectonic boundary is located further north than shown in the map of Searle \& Godin (2003). Geochronological data constrain fault movement along the STD in the interval 14-17 Ma (Harrison et al., 1999a), making the STD younger that the Manaslu crystallization age of 19-24Ma (Coleman, 1998; Harrison et al., 1999b). In addition, although detailed structural studies of large HHL are scarce, those available, including at Manaslu, have shown that the large plutons are, in general, characterized by the absence of strong penetrative deformation, which led early workers to infer the late 
kinematic character of the pluton intrusion with respect to the regional deformation (Le Fort, 1981). Magmatic lineations in the HHL plutons trend $\mathrm{E}-\mathrm{W}$ (Guillot et al., 1993; Scaillet et al., 1995a), and not N-S, as would be expected if intrusions occurred during a regional phase of $\mathrm{N}-\mathrm{S}$ extension.

In this study, we have considered two possible geometric relationships between the Manaslu granite and its top contact, either intrusive or faulted, to evaluate whether different models relating STD motion to HHL emplacement are supported by thermal constraints.

\section{Conditions during magma intrusion}

The $\mathrm{HHL}$ are characterized by the occurrence of magmatic muscovite, in addition to tourmaline and biotite (e.g. Le Fort et al., 1987). Experimental work by Benard et al. (1985) on the Manaslu granite shows that at $3 \mathrm{kbar}$, muscovite is not stable in fluorinepoor HHL compositions under magmatic conditions. Scaillet et al. (1995b) defined a stability field for muscovite at 4 kbar.

The stability curve of pure $\mathrm{OH}-$ muscovite intersects the wet haplogranite solidus in the pressure range 3-4 kbar (Fig. 2). Therefore, if devoid of fluorine, crystallization of muscovite in HHL constrains a minimum emplacement pressure of $\sim 3-5$ kbar. However, $\mathrm{HHL}$ do have some fluorine, which will extend the magmatic stability field of muscovite to lower pressures (Pichavant et al., 1988). HHL muscovites have 0.5-0.9 wt \% F (Scaillet, unpublished data) which would allow crystallization of muscovite down to 2.8 kbar (Pichavant et al., 1988), matching the pressure constraint derived by Guillot et al. (1995a, 1995b) for the top aureole. For $T$ and melt $\mathrm{H}_{2} \mathrm{O}$ content, petrological and experimental data show that the magma was near the liquidus on emplacement, with intrusion temperatures of $750-800^{\circ} \mathrm{C}$ and $5-7$ wt $\%$ dissolved $\mathrm{H}_{2} \mathrm{O}$ (Montel, 1993; Scaillet et al., 1995b, 1996).

The High Himalayan Crystallines, in particular the metapelites and metagreywacke of FI, are believed to be the protholiths of the $\mathrm{HHL}$, based on a variety of geological and geochemical arguments (Deniel et al., 1987; Le Fort et al., 1987; France-Lanord et al., 1988; Harris \& Inger, 1992; Inger \& Harris, 1993; Guillot \& Lefort, 1995; Harris et al., 1995; Searle et al., 1997). Harris \& Inger (1992) proposed, based on trace element modelling, that the $\mathrm{HHL}$ were produced by dehydration melting of muscovite-bearing metasediments, with melt fractions $<10 \mathrm{wt} \%$. This hypothesis is supported by the experimental work of Patino Douce \& Harris (1998), who showed that dehydration melting experiments on Himalayan metapelites (muscovite + plagioclase + quartz assemblage) in the pressure range 6-10 kbar yield melts that are virtually indistinguishable from the HHL (Fig. 2). We note that, in addition, the temperature and water contents of the experimental melts are the same as those inferred from nearliquidus phase equilibria of HHL (Scaillet et al., 1995b). These results support the view that the magma migrated upward with limited, if any, chemical or thermal modifications. There is field evidence that the $\mathrm{HHL}$ magmas moved upward through narrow dykes (Le Fort, 1981; Inger \& Harris, 1992; Scaillet et al., 1996; Walker et al., 1999), some of which connect to the base of the pluton, such as in the Garwhal Himalaya (Searle et al., 1993; Scaillet et al., 1995a). 


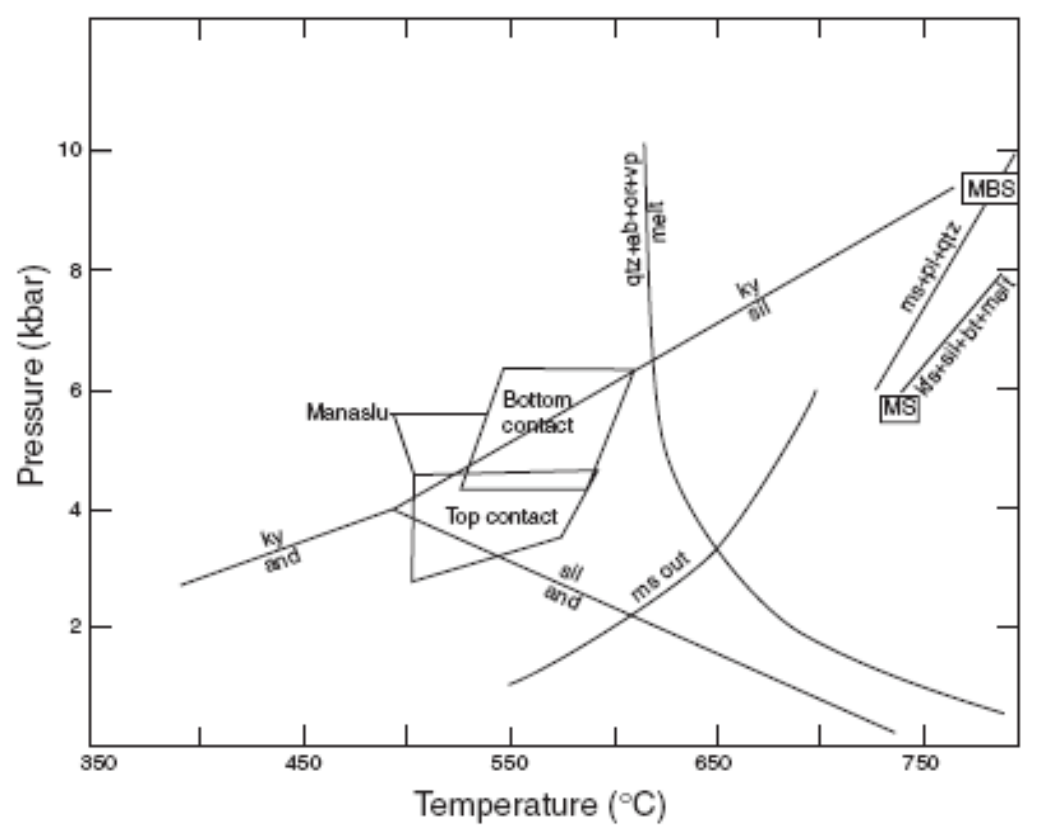

Fig. 2. P-T diagram showing the locations of the main dehydration melting reactions (MS, muscovite schist and MBS, muscovite-biotite schist) involving muscovite, obtained for two Himalayan metapelites by Patino Douce \& Harris (1998), together with the P-T conditions inferred for the top and bottom contact aureoles of Manaslu (Guillot et al., 1995a). Melting conditions of $\mathrm{HHL}$ are inferred to occur in the pressure range 6-10 kbar, whereas emplacement of $\mathrm{HHL}$ takes place at 3-4 kbar. Also shown are the haplogranite wet solidus (qz + ab + or $+3 v p)$ after Luth (1976) and the muscovite out (ms-out) curve of Chaterjee \& Johannes (1974). Note that both curves intersect at around 3 kbar, in agreement with phase equilibria constraints for the HHL (Benard et al., 1985; Scaillet et al., 1995b).

\section{Age constraints}

Although homogeneous in terms of their major element compositions (Le Fort et al., 1987), the $\mathrm{HHL}$ have $\mathrm{Rb}-\mathrm{Sr}$ and ${ }^{87} \mathrm{Sr}-{ }^{86} \mathrm{Sr}$ heterogeneities that have prevented accurate dating using the $\mathrm{Rb}-\mathrm{Sr}$ system, and which are believed to reflect heterogeneity in the source region (Vidal et al., 1982; Deniel et al., 1987; Inger \& Harris, 1993; Guillot \& Le Fort, 1995). $\mathrm{Rb}-\mathrm{Sr}$ heterogeneities indicate that the granites were not well mixed internally and that conditions for large-scale magma convection (which would homogenize the magma) were not reached (Deniel et al., 1987). Using U-Pb monazite ages, Coleman (1998) proposed that magmatic activity in the area of Manaslu occurred in two main pulses at 18 and 22Ma. Harrison et al. (1999b) determined $158 \mathrm{Th}-\mathrm{Pb}$ ages for monazite from 12 samples of the Manaslu granite. Based on the peak of the age distribution obtained for each sample, Harrison et al. (1999b) defined crystallization ages ranging from $19.0 \pm 0.4$ to $24.0 \pm 0.8 \mathrm{Ma}$. The histogram of all the Th- $\mathrm{Pb}$ monazite ages shows two distinct peaks, one around $19.3 \pm 0.3 \mathrm{Ma}$ and the other centred at $22.9 \pm 0.6$ Ma. The oldest ages correspond to samples from near the top of the body, whereas the 
youngest are from samples at the bottom. These results led Coleman (1998) and Harrison et al. (1999b) to conclude that the Manaslu granite was emplaced in two magma pulses separated in time by 4 Myr. The lack of intermediate ages between 19.6 and 22.0 Ma might, however, reflect a lack of sampling in the middle part of the intrusion. The age distribution shows a tail towards older ages which falls within the interval 24-37Ma, and an even older interval, between 100 and $600 \mathrm{Ma}$. The older interval can be ascribed to inheritance from a 500-600Ma crustal protolith, probably generated during the Cambro-Ordovician thermal event that produced the Lesser Himalayan granites and their metamorphosed equivalents in the HHC.Harrison et al. (1999b) interpreted the 24-37 Ma population as reflecting Eo-Himalayan metamorphism, i.e. the metamorphic phase that affected the HHC during the early stages of crustal stacking. However, this population might also record incipient stages of magma intrusion. We conclude that the time interval of laccolith growth of $5 \mathrm{Myr}$ should be viewed as a minimum value.

\section{THE NUMERICAL MODEL}

We simulated the growth of a laccolith-shaped granite body by the successive emplacement of discrete sills at magmatic temperature. In the Manaslu pluton, the youngest ages are stratigraphically located below the oldest (Harrison et al., 1999b) and so, in our model, each successive sill is emplaced below the previous one. The room for the sills is made by uplifting the overlying sediments or by moving the sequence below the sills downward. This latter case is an approximation for isostatic equilibration. In terms of computation, these two kinds of room accommodation correspond to two different bottom boundary conditions. For a room accommodation by isostatic equilibration, the bottom temperature is constant and at a fixed depth (Fig. 3b), whereas for a room accommodation by overlying sediments uplifting, the bottom temperature is also fixed but its depth is moving downwards relative to the surface level (Fig. 3c). We verified that the results were not sensitive to our assumptions about room accommodation. Two main models were tested. In the first one, magma sills are regularly injected throughout the entire magmatic event leading to the emplacement of 5 $\mathrm{km}$ of granite. In the second model, the same thickness of magma is emplaced in two pulses separated by a repose period of $4 \mathrm{Myr}$, as proposed by Harrison et al. (1999b). The sills are accreted in the same way as in the first model until the body is $2.5 \mathrm{~km}$ thick, then magma injection stops. After $4 \mathrm{Myr}$ of no magmatism, intrusions resume and the remaining $2.5 \mathrm{~km}$ are emplaced at the same rate as in the first pulse. It should be noted that the thickness of the Manaslu granite has been estimated to reach $8 \mathrm{~km}$ in some areas (Guillot et al., 1995a), so that the $5 \mathrm{~km}$ total thickness is conservative. 


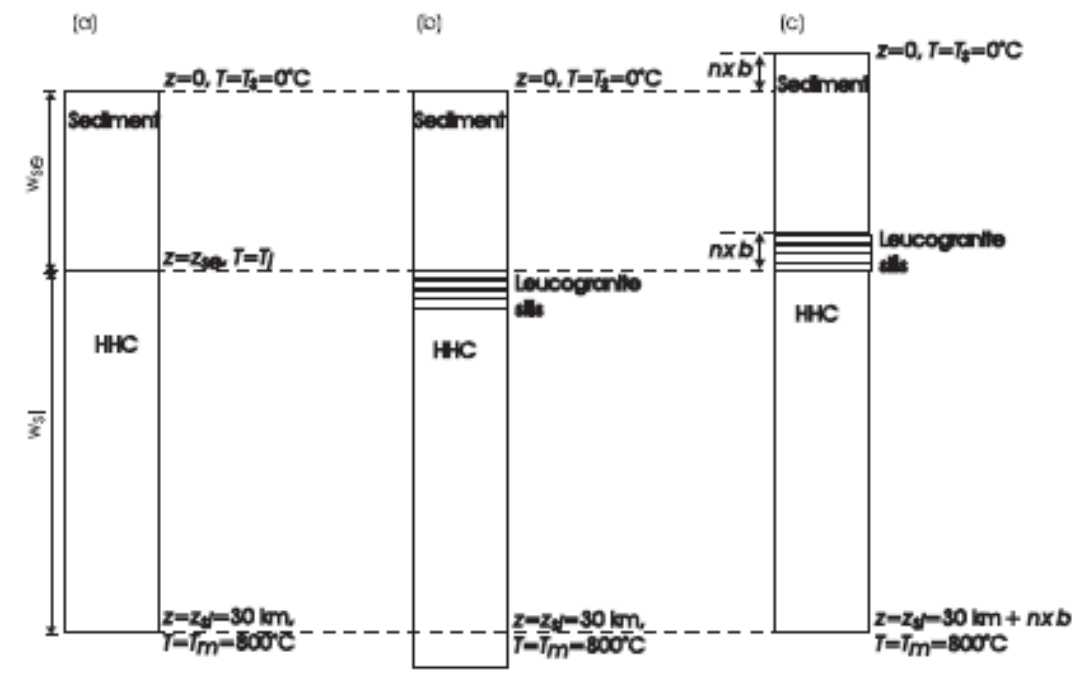

Fig. 3. One-dimensional model of emplacement of a large igneous body by discrete sill accretion. (a) Initial conditions; (b) and (c) after the intrusion of $n$ sills. In (b) the volume of the sills is accommodated by 'isostasy' (sagging) and the bottom boundary $T=800^{\circ} \mathrm{C}$ is at a fixed depth $(z=30 \mathrm{~km})$; in (c) the volume of the sills is accommodated by roof uplift: the bottom boundary $T=800^{\circ} \mathrm{C}$ is at $30 \mathrm{~km}+\mathrm{nb}$, with b the sill thickness. For abbreviations see Table 1.

The media, i.e. the granite and the country rock layers, are discretized and the temperature evolution is computed using the finite difference expression of the equation of heat balance :

$$
\rho C_{\rho} \frac{\delta T}{\delta \ell}=k \nabla T+\rho L+A
$$

where $p$ is density, $C_{p}$ is specific heat capacity, $T$ is temperature, $t$ is time, $k$ is thermal conductivity, $L$ is latent heat of fusion or crystallization, and $A$ is radioactive heat production. Values of these parameters used in the model are given in Table 1. 


\begin{tabular}{|c|c|c|c|c|c|c|}
\hline \multicolumn{4}{|c|}{ Fixed parameters } & \multirow{2}{*}{\multicolumn{2}{|c|}{$\begin{array}{l}\text { Values } \\
2700\end{array}$}} & \multirow{2}{*}{$\begin{array}{l}\text { Units } \\
\mathrm{kg} / \mathrm{m}^{3}\end{array}$} \\
\hline \multicolumn{2}{|l|}{$P_{\mathrm{se}}$} & \multicolumn{2}{|l|}{ Sediment density } & & & \\
\hline$p_{g}$ & & \multicolumn{2}{|l|}{ Granite density } & \multicolumn{2}{|l|}{2300} & $\mathrm{~kg} / \mathrm{m}^{3}$ \\
\hline \multicolumn{2}{|l|}{$P_{s l}$} & \multicolumn{2}{|l|}{ HHC density } & \multicolumn{2}{|l|}{2700} & $\mathrm{~kg} / \mathrm{m}^{3}$ \\
\hline \multicolumn{2}{|c|}{$C_{p s e}$} & \multicolumn{2}{|l|}{ Sediment-specific heat capacity } & \multicolumn{2}{|l|}{1000} & $\mathrm{~J} / \mathrm{kg} / \mathrm{K}$ \\
\hline \multicolumn{2}{|l|}{$C_{p g}$} & \multicolumn{2}{|l|}{ Granite-specific heat capacity } & \multicolumn{2}{|l|}{1600} & $\mathrm{~J} / \mathrm{kg} / \mathrm{K}$ \\
\hline \multicolumn{2}{|l|}{$C_{p s l}$} & \multicolumn{2}{|l|}{ HHC-specific heat capacity } & \multicolumn{2}{|l|}{1000} & $\mathrm{~J} / \mathrm{kg} / \mathrm{K}$ \\
\hline \multicolumn{2}{|l|}{$k_{g}$} & \multicolumn{2}{|l|}{ Granite conductivity } & \multicolumn{2}{|c|}{3} & $\mathrm{~W} / \mathrm{m} / \mathrm{K}$ \\
\hline \multicolumn{2}{|l|}{$A_{s e}$} & \multicolumn{2}{|l|}{ Sediment radioactive heat production } & \multicolumn{2}{|l|}{$1.4 \times 10^{-6}$} & $\mathrm{~W} / \mathrm{m}^{3}$ \\
\hline \multicolumn{2}{|l|}{$A_{g}$} & \multicolumn{2}{|l|}{ Granite radioactive heat production } & \multicolumn{2}{|l|}{$5 \cdot 3 \times 10^{-6}$} & $\mathrm{~W} / \mathrm{m}^{3}$ \\
\hline \multicolumn{2}{|l|}{$A_{s l}$} & \multicolumn{2}{|l|}{$\mathrm{HHC}$ radioactive heat production } & \multicolumn{2}{|l|}{$2 \cdot 7 \times 10^{-6}$} & $\mathrm{~W} / \mathrm{m}^{3}$ \\
\hline \multicolumn{2}{|l|}{$\alpha_{v}$} & \multicolumn{2}{|l|}{ Magma volumetric coefficient of thermal expansion } & \multicolumn{2}{|l|}{$2 \times 10^{-5}$} & $/ \mathrm{K}$ \\
\hline \multicolumn{2}{|c|}{ wt \% $\mathrm{H}_{2} \mathrm{O}$} & Melt water content & & 5 & & $\%$ \\
\hline Test & para & & Ranges & & Units & \\
\hline$k_{s e}$ & $\mathrm{Sec}$ & nt conductivities & $2-5$ & & $\mathrm{~W} / \mathrm{m} / \mathrm{K}$ & \\
\hline$k_{s l}$ & $\mathrm{HH}$ & nductivities & $2-3$ & & $\mathrm{~W} / \mathrm{m} / \mathrm{K}$ & \\
\hline$T_{i}$ & Initi & mperatures at emplacement level & $250-350$ & & ${ }^{\circ} \mathrm{C}$ & \\
\hline$b$ & Sill & kness & $20-100$ & & $\mathrm{~m}$ & \\
\hline$Q$ & $\mathrm{Ma}$ & emplacement rates & $0 \cdot 1-4 \cdot 0$ & & $\mathrm{~mm} / \mathrm{yea}$ & \\
\hline$W_{s e}$ & 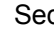 & nt thickness = granite roof depth & $10-15$ & & $\mathrm{~km}$ & \\
\hline
\end{tabular}

Table 1: Model input parameters

Models were tested for sill thicknesses from 5 to $1000 \mathrm{~m}$. Preliminary results showed that only thin sills produced results consistent with the geological observations (small aureole size). Additionally, Deniel et al. (1987) found that the scale length of the Rb-Sr heterogeneities was $100 \mathrm{~m}$. Thus, most simulations were run with sills of thickness $50 \mathrm{~m}$. The convergence of the results was tested for different node spacing. For models with sills $50 \mathrm{~m}$ thick or more, the node spacing was $25 \mathrm{~m}$. For thinner sills, the node spacing was equal to the thickness of the sill. The top of the intrusion was emplaced at a pressure of 3-4 kbar (Guillot et al., 1995a). We tested our model with granite top depth, i.e. depths of the first intruded sill, at $10,12.5$ and $15 \mathrm{~km}$. We assumed that the granite magma temperature at $30 \mathrm{~km}$ depth was $800^{\circ} \mathrm{C}$ and that the adiabatic drop between 30 $\mathrm{km}$ and the emplacement level is about $20^{\circ} \mathrm{C}$, resulting in a modelled leucogranite emplacement temperature of $780^{\circ} \mathrm{C}$. We also ran some tests with an emplacement temperature of $750^{\circ} \mathrm{C}$ to check the influence of lower temperature on the results. We did not consider temperatures lower than $750^{\circ} \mathrm{C}$ because melt fractions in partially melted 
Himalayan metapelites are below 5 wt $\%$ in the temperature range $720-750^{\circ} \mathrm{C}$ (Patino Douce \& Harris, 1998) and it is unlikely that such partial melts will easily move out of their source but, instead, will remain trapped within it.

\section{Conductivities}

Heat transfer in a material is governed by the material heat diffusivity, $\mathrm{k}$ :

$$
\kappa=\frac{k}{\rho C_{p}}
$$

Density and specific heat capacity change only slightly with rock composition. Conductivity strongly depends on rock composition and on pore water or air content (Robertson, 1988). Rock conductivity is especially sensitive to quartz content, because of its high conductivity $(7.69 \mathrm{~W} / \mathrm{m} / \mathrm{K})$. Depending on quartz content, sedimentary and felsic igneous rocks have conductivities ranging from 1.5 to $>6 \mathrm{~W} / \mathrm{m} / \mathrm{K}$ (Robertson, 1988). If the mode of the rock is known, its conductivity can be estimated as follows (Robertson, 1988):

$$
k=n_{1} k_{1}+n_{2} k_{2}+n_{3} k_{3}+\cdots
$$

where $n 1, n 2, n 3$ are fractional volumes of mineral phases $1,2,3$ and $\mathrm{k}_{1}, \mathrm{k}_{2}, \mathrm{k}_{3}$ are conductivities of mineral $1,2,3$. Conductivities decrease with increasing temperature (Robertson, 1988; Chapman \& Furlong, 1992; Clauser \& Huenges, 1995), but this decrease is poorly constrained and might be balanced by an increase in radiative heat transfer (Jaupart \& Provost, 1985). The average HHL leucogranite quartz content is $32 \%$ (Le Fort et al., 1987). At the pressure of emplacement (3-4 kbar), porosity is assumed to be negligible. We estimate a granite conductivity of $3.2 \mathrm{~W} / \mathrm{m} / \mathrm{K}$ at room temperature, in agreement with data for other gneisses and granites (Roy et al., 1968; Wenk \& Wenk, 1969; Jaupart \& Provost, 1985; Robertson, 1988). The quartz content of Himalayan metasedimentary rocks varies from $<20 \%$ to $>70 \%$ (France-Lanord, 1987), corresponding to conductivities in the range of $2-6 \mathrm{~W} / \mathrm{m} / \mathrm{K}$ (Robertson, 1988). The TSS are characterized by an alternation of limestones, sandstones and shales (Colchen et al., 1986). Sandstones should have the highest conductivity, because of their high quartz content, followed by limestones and then shales. Conductivities of representative Himalayan metapelites of the $\mathrm{HHC}$ have room temperature conductivities in the range 3.2-5.3 W/m/Kwith an average of $3.7 \pm 0.8 \mathrm{~W} / \mathrm{m} / \mathrm{K}$ (Table 2 ). The conductivity of calcite is lower than that of quartz $(3.57 \mathrm{~W} / \mathrm{m} / \mathrm{K}$ at room $\mathrm{T})$ and is taken as the value for limestone. At $10 \mathrm{~km}$ depth, the conductivity of shale is estimated to be around $1.7 \mathrm{~W} / \mathrm{m} / \mathrm{K}$ (Gueguen \& Palciauskas, 1992). Forty-seven per cent of the TSS is made of limestones, $23 \%$ of sandstones and the remaining $30 \%$ of shales (Colchen et al., 1986), suggesting an average conductivity of $3.6 \mathrm{~W} / \mathrm{m} / \mathrm{K}$. Limestones are dominant at the base of the pile 
(Paleozoic), shales are more abundant upsequence, and sandstones are more or less evenly distributed throughout (Colchen et al., 1986).

Table 2: HHC metasediment and Manaslu leucogranite modal mineralogy and conductivities

\begin{tabular}{|c|c|c|c|c|c|c|c|c|c|}
\hline & $\begin{array}{l}k_{i} \\
(\mathrm{~W} / \mathrm{m} / \mathrm{K})\end{array}$ & $\begin{array}{l}\text { Density } \\
\left(\mathrm{g} / \mathrm{cm}^{3}\right)\end{array}$ & $\begin{array}{l}\text { NA410 } \\
\text { vol \% }\end{array}$ & $\begin{array}{l}\text { NA411 } \\
\text { vol \% }\end{array}$ & $\begin{array}{l}\text { MS } \\
\text { vol \% }\end{array}$ & $\begin{array}{l}\text { MBS } \\
\text { vol \% }\end{array}$ & $\begin{array}{l}\text { HS-1 } \\
\text { vol \% }\end{array}$ & $\begin{array}{l}\text { HS-2 } \\
\text { vol \% }\end{array}$ & $\begin{array}{l}\text { Manaslu } \\
\text { wt \% }\end{array}$ \\
\hline Quartz & $7 \cdot 69$ & $2 \cdot 65$ & 63 & 36 & 43 & 38 & 35 & 40 & 32 \\
\hline Mica & $0 \cdot 4$ & 3 & 11 & 40 & 24 & 42 & 30 & 35 & 10 \\
\hline Plagioclase 2 & $2 \cdot 7$ & 25 & 21 & 28 & 11 & 15 & 30 & 37 & \\
\hline KFd & $2 \cdot 4$ & $2 \cdot 55$ & - & - & - & - & - & - & 21 \\
\hline$k(\mathrm{~W} / \mathrm{m} / \mathrm{K})$ & & & $5 \cdot 3$ & $3 \cdot 2$ & $3 \cdot 9$ & $3 \cdot 2$ & $3 \cdot 0$ & $3 \cdot 7$ & $3 \cdot 2$ \\
\hline
\end{tabular}

All conductivities are calculated using equation (3). $k_{i}$ is the mineral conductivity. Metasediment compositions are from: NA410, NA411: Colchen et al. (1986); MS, MBS: Patiño Douce \& Harris (1998); HS-1, HS-2: (Harris \& Inger, 1992); the Manaslu leucogranite composition is from Guillot et al. (1995a). The modal compositions of NA410 and NA411 are calculated by mass balance using the bulk-rock compositions listed by Colchen et al. (1986), and the mineral compositions of Patiño Douce \& Harris (1998).

The TSS is thus more conductive at its base than at its top. Local conductivity variations are expected at the contact with the granite, depending on the local lithology. Although realistic values for TSS conductivities are in the range of $2.5-4 \mathrm{~W} / \mathrm{m} / \mathrm{K}$, we have tested thermal conductivities of TSS spanning a large range of $2-5 \mathrm{~W} / \mathrm{m} / \mathrm{K}$ in order to constrain the role of this parameter better. Hydrothermal convection can increase heat transfer and the apparent conductivity. A minimum permeability, $\mathrm{K}$, is required for the onset of convection. According to the theory of fluid convection in a porous medium (Turcotte \& Schubert, 1982),

$$
K=\frac{R a \mu_{f} k_{s e}}{\alpha_{f} g \rho_{f}^{2} c_{p f} w_{s e} \Delta T}
$$

where $\mu_{f}, \alpha_{f}$, af and $c_{p f}$ are the fluid viscosity, density, volumetric coefficient of thermal expansion and specific heat capacity; kse and wse are the sediment conductivity and thickness. Assuming conservative values of $R a$ (Rayleigh number) $=4 \pi^{2}, \mu_{f}=1.33 \cdot \times 10^{-}$ ${ }^{4} \mathrm{~Pa} \mathrm{~s}, k_{\mathrm{se}}=2 \mathrm{~W} / \mathrm{m} / \mathrm{K}$, of $1 / 410^{-3} / \mathrm{K}, p_{f}=1000 \mathrm{~kg} / \mathrm{m} 3, c_{p f}=4200 \mathrm{~J} / \mathrm{kg}, w_{s e}=10000 \mathrm{~m}$ and $\Delta T=500^{\circ} \mathrm{C}$, we obtain a minimum value for log $K$ of -16.3 . The log of rock permeability at $10 \mathrm{~km}$ depth can be estimated from experimental data (Shmonov et al., 2003) at -18.1 or from geothermal data at -17.2 (Ingebritsen \& Manning, 1999). We conclude that permeabilities will be too low for hydrothermal convection to occur. The absence of 
mineralization and veining close to the HHL plutons also suggests that there was no pervasive hydrothermal system surrounding the granite.

\section{Boundary and initial conditions}

The top boundary condition at the Earth's surface is a fixed temperature of $0^{\circ} \mathrm{C}$. The bottom boundary condition is a magmatic temperature of $800^{\circ} \mathrm{C}$, located at a depth of 30 $\mathrm{km}$ (Fig. 3). The initial temperature in the crust is determined by the geothermal gradient. A geothermal gradient at equilibrium can be calculated, where surface heat flux balances the heat flux from the base of the HHC and the internal heat production. The equations describing this steady-state geothermal gradient are given in the Appendix. The equilibrium geothermal gradient and the consecutive crust total heat content are controlled by the HHC and sediment conductivities (Fig. 4).

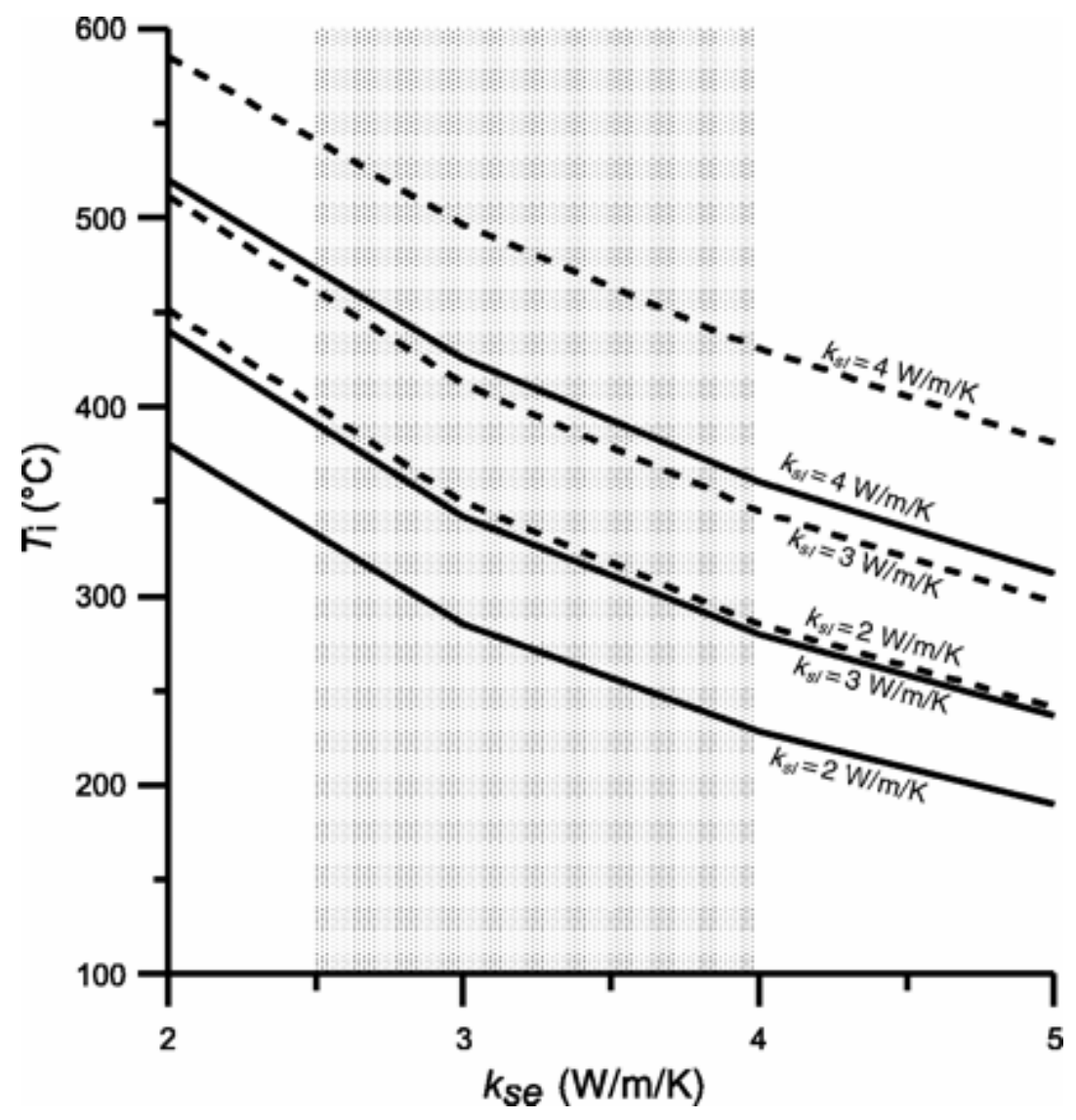

Fig. 4. Equilibrium temperature $T_{i}$ at the $\mathrm{HHC}$-sediment interface for different sediment conductivities $k_{\mathrm{se}}$ and $\mathrm{HHC}$ conductivities $k_{s /} . T_{i}$ is calculated with the equation in the Appendix for a steady-state geothermal gradient. The grey shaded area indicates the range of realistic values for the sediment conductivities. The continuous and dashed curves are for $\mathrm{HHC}$-sediment interfaces at 10 and $12.5 \mathrm{~km}$ depth respectively. 
Because, in an active orogenic belt, the geothermal gradient is probably not at equilibrium, we tested the model with initial temperature at emplacement level $\mathrm{Ti}$ of 250 , 300 and $350^{\circ} \mathrm{C}$. In this case, the initial geothermal gradient is linear between the magmatic temperature at depth $\left(T_{m}=800^{\circ} \mathrm{C}\right.$ at $\left.30 \mathrm{~km}\right)$ and the temperature, $\mathrm{Ti}$, at the granite emplacement level, and between $\mathrm{Ti}$ and the surface temperature $\left(0^{\circ} \mathrm{C}\right)$. With a linear geothermal gradient, the temperature of the crust evolves with time and tends toward the equilibrium geothermal profile, which is controlled by rock conductivities. As discussed later, this drift toward the equilibrium profile affects the results. The results presented below show that the thermal evolution during granite emplacement is governed by the equilibrium temperature at the locus of intrusion.Most results are in fact weakly dependant on the initial temperature. This, in turn, shows that they are not strongly dependent on the extent of thermal disequilibrium of the geotherm because of orogenic process.

\section{Latent heat of crystallization and metamorphism}

The latent heat released during crystallization is derived from phase equilibrium experiments performed on $\mathrm{HHL}$ at 4 kbar (Scaillet et al., 1995b). Closed-system crystallization is assumed and the cumulated latent heat is calculated by estimating quartz, plagioclase and alkali feldspar proportions as a function of temperature and $\mathrm{H}_{2} \mathrm{O}$ in the melt. The role of accessory phases such as micas and tourmaline, which amount to less than $5 \%$ of the minerals, is neglected.

Because the $\mathrm{HHL}$ are highly evolved magmas, it follows that their curves of crystallization and, thus, of latent heat release are highly non-linear with temperature (Scaillet et al., 1997). Based on fits to experimental data, the expressions for HHL latent heat used in the modelling are

$$
L(T\}=\left\{\begin{array}{l}
4.9204 \times 10^{5}-463.72(T+\mathrm{d} T) \\
: 928 \mathrm{~K}<T+\mathrm{d} T<1061 \mathrm{~K} \\
2.5636 \times 10^{7}-2.7571 \times 10^{4}(T+\mathrm{d} T) \\
: 900 \mathrm{~K}<T+\mathrm{d} T<928 \mathrm{~K} .
\end{array}\right.
$$

where $L(T)$ is cumulated latent heat in $\mathrm{J} / \mathrm{kg} ; T$ is in $\mathrm{K}$. The term $\mathrm{d} T$ is a correction for pressures different from $4 \mathrm{kbar}$ and is equal to $-15(P-4)$ with $P$ in kbar. The latent heat released by the magma cooling from temperature $T_{1}$ to $T_{2}$ is $L\left(T_{2}\right)-L\left(T_{1}\right)$. As $T_{2}$ depends on the latent heat released, the solution to equation (1) is found numerically by iteration.

To evaluate the effect of latent heat of metamorphic reactions on the aureole size and temperature, some runs have been performed by including the latent heat absorbed by muscovite and biotite dehydration between 400 and $600^{\circ} \mathrm{C}$ using a latent heat of 600 $\mathrm{J} / \mathrm{kg} / \mathrm{K}$ (Furlong et al., 1991).

\section{Comparison with nature: convection and thermal aureole}

The constraints imposed by observations on the HHL are the absence of large-scale convection within the magma body and a thermal aureole less than $100 \mathrm{~m}$ thick. We 
carried out a parametric study to determine the conditions that are consistent with these characteristics.

Convection within an individual sill will happen on short time-scale before it crystallizes. We considered the convection extending to more than two sill thicknesses. We assume that the conditions for convection are reached in the leucogranites when the Rayleigh number, Ra, exceeds 3000 (Sparks et al., 1984):

$$
R a=\frac{\rho g \alpha_{v} \Delta T w_{m}^{3}}{\mu \kappa}
$$

where pis density, $\alpha_{V}$ is the volumetric coefficient of thermal expansion, $\Delta T$ is temperature difference between the top and bottom of the fluid layer, $w_{m}$ is the thickness of the magmatic layer, and $\mu$ is magma viscosity. The melt viscosity of $\mathrm{HHL}$ has been experimentally determined between 800 and $1100^{\circ} \mathrm{C}$, between 3 and $8 \mathrm{kbar}$, for $\mathrm{H}_{2} \mathrm{O}$ contents between 3.98 and 6.66 wt \% (Scaillet et al., 1996) :

$$
\log \left(\mu_{0}\right)=\frac{16280}{T}-7 \cdot 5461+\left(0.59784-\frac{1235 \cdot 4}{T}\right) X_{\mathrm{H}_{2} \mathrm{O}}
$$

where $\mu_{0}$ is melt viscosity in $\mathrm{Pa} \mathrm{s}, T$ is in $\mathrm{K}$ and $X_{\mathrm{H} 2 \mathrm{O}}$ is the $\mathrm{H}_{2} \mathrm{O}$ content expressed as a weight percentage of the melt. In our model, the $\mathrm{H}_{2} \mathrm{O}$ content is $5 \mathrm{wt} \%$.

Below the liquidus, the presence of crystals modifies the magma bulk viscosity (Roscoe, 1952; Lejeune \& Richet, 1995):

$$
\mu=\mu_{0}\left(1-\frac{\Phi}{\Phi_{m}}\right)^{-n}
$$

where $\Phi^{\text {is }}$ crystal fraction, $\Phi_{m}$ is the critical crystal fraction beyond which flow is prevented, and $n$ is a constant. The form of equation (8) reflects the large increases in viscosity that occur when crystallization is sufficient for the crystals to develop a touching framework in the transition between a crystal-rich magma and a partially molten rock. Based on experimental and empirical evidence (Marsh, 1981; Lejeune \& Richet, 1995), we take $\Phi_{m}=0.6$ and $n=2.5$ as typical values. The viscosity becomes infinite as $\Phi$ tends to $0 \cdot 6$. The model results are not sensitive to the shape of the viscosity curve because, in the case of the $\mathrm{HHL}$, the curve of crystallization is close to the eutectic and 1 increases from 0 to 0.75 over a temperature range of about $20^{\circ} \mathrm{C}$. The crystal fraction at any given temperature between the solidus and the liquidus is estimated from the experimental results of Scaillet et al. (1995b) and has been given by Scaillet etal. (1997).

The modelling is based on the assumption that large-scale convection within the granite would have homogenized $\mathrm{Rb}-\mathrm{Sr}$. This assumption is supported by the results of Jellinek et al. (1999), who showed that convection efficiently mixes fluids with low viscosity 
contrasts, even at low Reynolds number. Moreover, as discussed above, the magma has an eutectic behaviour. As a consequence, rapid changes of viscosity occur over a very narrow temperature window and the viscosities become relatively low just above the eutectic temperature; thus, the sluggish convection regime is expected to be confined to very restricted conditions.

Application of equation (6) using a characteristic $\mathrm{HHL}$ magma viscosity of $10^{5} \mathrm{~Pa}$ and a $\Delta T$ of $2^{\circ} \mathrm{C}$, using the input parameters listed in Table 1 , shows that Ra exceeds 3000 for any sill thicker than $20 \mathrm{~m}$. For instance, for a sill $100 \mathrm{~m}$ thick, $R a=3.7 \times 10^{5}$, which indicates that convection can be attained in relatively thin HHL sills, even when the thermal gradient across the magma layer is very small. In this paper, we distinguish between small-scale convection in an individual sill and large-scale convection on a scale of more than two sill thicknesses. In all our models, the time-scale for a thin sill to come to thermal equilibration with its surroundings is much shorter than the repose period between intrusions. Thus, it is possible for individual sills to convect during their cooling, but large-scale convection does not develop. Bergantz and Dawes (1994) argued that with a realistic set of parameters and assumptions, convective models of heat transfer in magma do not give fundamentally different results from purely conductive models. Thus, local convection should not increase significantly the heat transfer. The possible slight increase of heat transfer that would be related to small-scale convection is accounted for by the wide range of thermal conductivity that we explored.

The other observation we used to constrain the magma emplacement rate is the thermal aureole thickness, $w_{t}$. In the model, $w_{t}$ was defined as the thickness of country rock whose temperature has exceeded $400^{\circ} \mathrm{C}$ during the magmatic event.

The two constraints (absence of large-scale convection and a narrow thermal aureole) were tested independently. No assumption was made about the size of the thermal aureole when the conditions for the absence of convection were explored and, similarly, no assumption was made about the occurrence of convection when we studied the size of the thermal aureole.

\section{Model limitations}

We developed a one-dimensional model, which allowed us to test a large set of parameters. Such a detailed parameter study would not have been possible with a twodimensional model. However, using a one-dimensional model implies that on long timescales, the temperatures might be overestimated because horizontal heat loss is neglected. This time-scale can be approximated as follows (Turcotte \& Schubert, 1982):

$$
t=\frac{L^{2}}{\kappa} \text {. }
$$

For a body that is $10 \mathrm{~km}$ wide, the time-scale for lateral heat flow is about $4.5 \mathrm{Myr}$. If the time-scale of the granite emplacement is no more than $5 \mathrm{Myr}$, as suggested by Harrison et al. (1999b), the lateral heat flow can be neglected. At lower granite emplacement rates, we will show later that the thermal evolution of the system is controlled by 
individual sills cooling on time-scales much shorter than 4.5 Myr and thus that the lateral heat flow is insignificant.

Conductivity anisotropy is not captured by our one-dimensional model. We have modelled the country rock as homogeneous but, as stressed above, the sediments and crystalline basement surrounding the $\mathrm{HHL}$ are layered and probably have conductivity variations.

The heat advected by the fluids exsolved by the crystallizing granite is not included in the model. Fluid advection would increase the size and temperature of the thermal aureole. Thus, the results we obtained are conservative.

\section{RESULTS}

The thermal evolution of the system To constrain the conditions that give rise to a thin thermal aureole and the absence of large-scale convection, we made a parametric study on rock conductivities, magma emplacement rates, emplacement depths, initial temperatures and individual sill thicknesses. Early sills injected into cold crust solidify and transfer their heat to the country rock. The consecutive temperature evolution in the growing granitic body and in the surrounding crust is the result of a competition between the sensible and latent heat advected by the magma, and the heat dissipated toward the surface by conduction. Thus, the parameters that control the thermal evolution of the system are the magma emplacement rate and rock thermal conductivity. If more heat is advected than can be conducted away, the temperatures increase in the granite and country rocks, resulting in the growth of a contact thermal aureole. Eventually, newly injected sills equilibrate at temperatures above the leucogranite solidus. The intruding sills do not completely solidify any more and a zone of granite containing residual melt starts to accumulate. If the conditions described by equation (6) are satisfied, the magma convects and the intrusions begin to amalgamate and homogenize.

\section{Conditions for convection}

We define a critical granite thickness, which corresponds to the total granite thickness that is accreted before large-scale convection initiates. We first illustrate how magma emplacement rate and country rock conductivity influence the critical granite thickness (Fig. 5). 


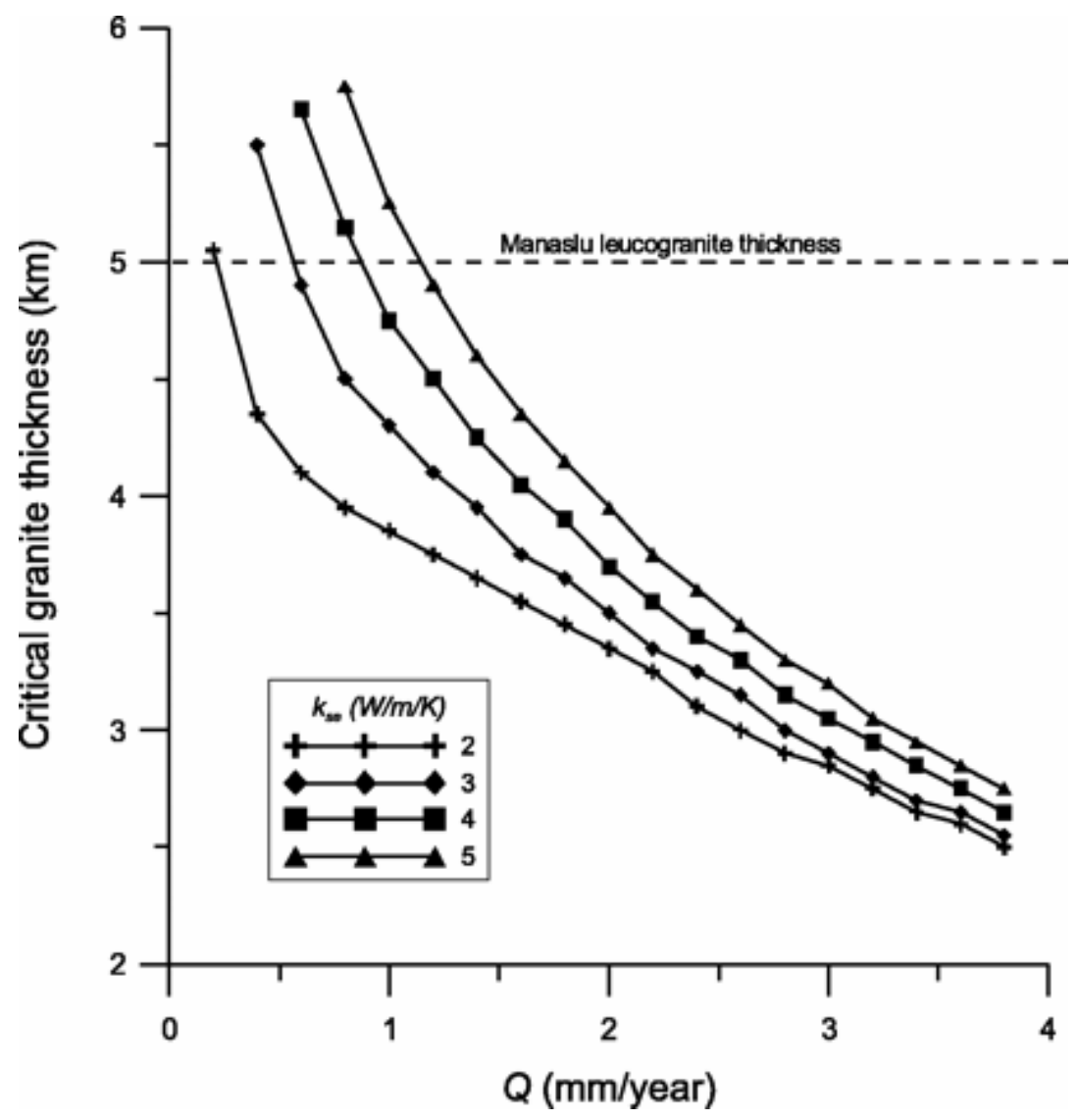

Fig. 5. Critical granite thickness that needs to be emplaced before conditions for convection are reached as a function of magma emplacement rate $(Q)$, for different overlying sediment conductivities $\left(k_{s e}\right)$. The critical emplacement rate for the Manaslu ( $\sim 5 \mathrm{~km}$ thick) is defined by the intersection of the curves with the dashed line. The sill thickness is $50 \mathrm{~m}$, the granite conductivity is $3 \mathrm{~W} / \mathrm{m} / \mathrm{K}$, the $\mathrm{HHC}$ conductivity is $2 \mathrm{~W} / \mathrm{m} / \mathrm{K}$, the initial $\mathrm{HHC}$-sediment boundary is at 12.5 $\mathrm{km}$, and the initial geothermal gradient is linear with the $\mathrm{HHC}$-sediment interface temperature $T_{i}=300^{\circ} \mathrm{C}$.

For the Manaslu body, no large-scale convection happened; thus, the critical thickness was larger than the thickness of the body. For the calculation conditions shown in Fig. 5-a granite roof at $12.5 \mathrm{~km}$ depth and no repose period-emplacement rates decrease with sediment conductivity. An average TSS conductivity of $4 \mathrm{~W} / \mathrm{m} / \mathrm{K}$ or less constrains the maximum emplacement rate to $<0.8 \mathrm{~mm} /$ year; this value corresponds to the emplacement of $5 \mathrm{~km}$ of granite in $6 \cdot 25 \mathrm{Myr}$.

In the parametric study, we use the critical emplacement rate, $Q_{c}$, which is the maximum emplacement rate allowing $5 \mathrm{~km}$ of leucogranite to be emplaced without onset of largescale convection. Figure 6 shows the relationships between $Q_{c}$ and the sediment conductivities, with and without the repose period, for injection depths of 10, 12.5 and 15 $\mathrm{km}$ and for $\mathrm{HHC}$ conductivities of 2 and $3 \mathrm{~W} / \mathrm{m} / \mathrm{K}$. As shown before, high sediment conductivities allow fast cooling and high $Q_{c}$. High $Q_{c}$ is also favoured by low $\mathrm{HHC}$ conductivities, because less heat comes from depth, and by shallow injection depth (Fig. $\underline{6}$ ). The initial temperature, $T_{i}$, at the locus of magma emplacement does not influence $Q_{c}$ significantly. With a shallow granite roof depth $(10 \mathrm{~km})$, a 4 Myr period of repose allows $Q_{c}$ for each magma pulse to be higher than $Q_{c}$ for continuous emplacement, because 
the crust is cooling down during the repose period. At greater depths, the difference in emplacement rate between the two models is small (Fig. 6). According to these results, the emplacement rate of the Manaslu granite is estimated to be less than $1.6 \mathrm{~mm} /$ year if emplacement is continuous and $<2.3 \mathrm{~mm} / \mathrm{year}$ with a $4 \mathrm{Myr}$ repose. The granite emplacement duration is obtained by dividing $5 \mathrm{~km}$ by the emplacement rate. To this duration, 4 Myr must be added in the case of a repose period. Thus, although each magma pulse emplacement rate is higher in the case of two magma pulses, the averaged emplacement rate is lower and the emplacement duration is longer (ig. 6 ).
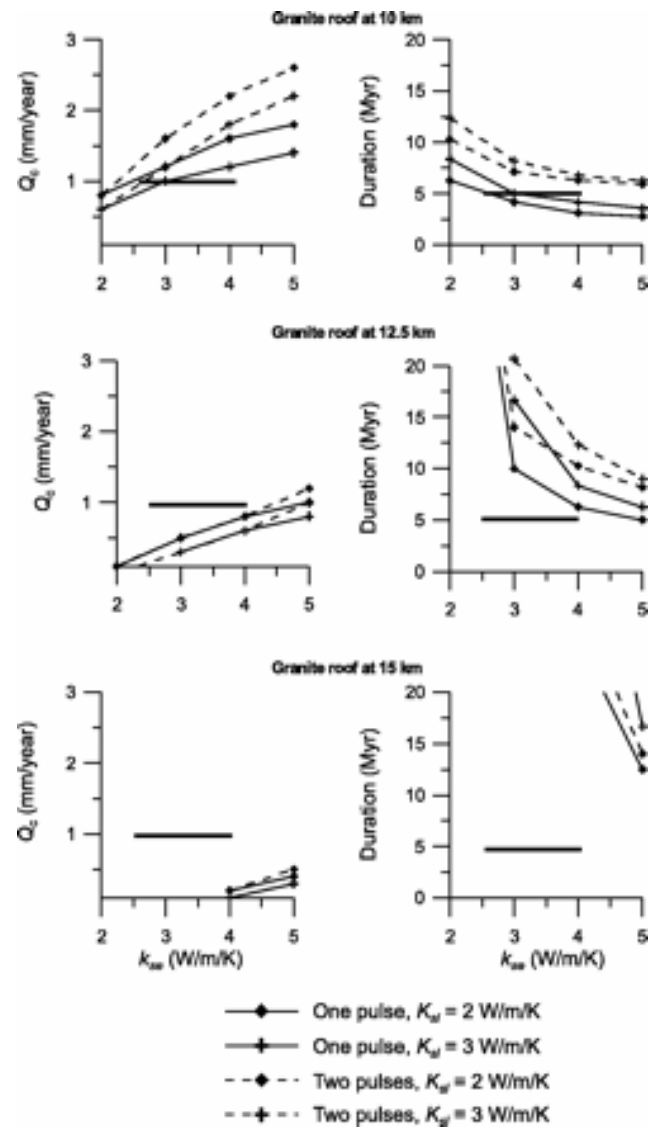

Fig. 6. Critical emplacement rate for convection $\left(Q_{c}\right)$, and total emplacement duration, corresponding to a critical granite thickness of $5 \mathrm{~km}$, for different sediment conductivities $k_{s e}, \mathrm{HHC}$ conductivities $k_{s}$, and initial HHC-sediment interface depths. Continuous lines: sills are regularly injected during the emplacement of $5 \mathrm{~km}$ of granite; dashed lines: sills are emplaced in two magmatic pulses separated by a repose period of 4 Myr as suggested by Harrison et al. (1999b). The thick horizontal line marks the range of realistic sediment conductivities and Manaslu emplacement rates or duration inferred from geochronological data (Harrison et al., 1999b). These results are for a leucogranite injection temperature of $780^{\circ} \mathrm{C}$. The maximum difference in $Q_{c}$ for a lower injection temperature of $750^{\circ} \mathrm{C}$ is 0.2 $\mathrm{mm} /$ year.

According to Harrison et al. (1999b), the age difference between the Manaslu top and bottom is 5 Myr. Figure 6 suggests that this emplacement duration is consistent with the absence of convection if the emplacement depth is shallow (granite roof at $10 \mathrm{~km}$ ). For a granite roof at $12.5 \mathrm{~km}$, emplacement durations of $5 \mathrm{Myr}$ are possible only with unrealistic sediment conductivities $(>4.5 \mathrm{~W} / \mathrm{m} / \mathrm{K})$. At depths of $15 \mathrm{~km}$ or more, forming a $5 \mathrm{~km}$ thick pluton in $5 \mathrm{Myr}$ results in convection, using reasonable values of sediment 
conductivities. This suggests that the preservation of isotopic heterogeneities within the thickest $\mathrm{HHL}$ is not consistent with a deep intrusion level, assuming a static overlying column. Although we have not tested initial temperatures, $T_{i}$, at the locus of magma intrusion hotter than $350^{\circ} \mathrm{C}$, the above results do not substantiate the case for in situ partial melting to construct the plutons. Intrusion in a deep environment (i.e. middle crust) will make it very difficult to avoid convection and mixing within thick $\mathrm{HHL}$ laccoliths.

\section{The thermal aureole}

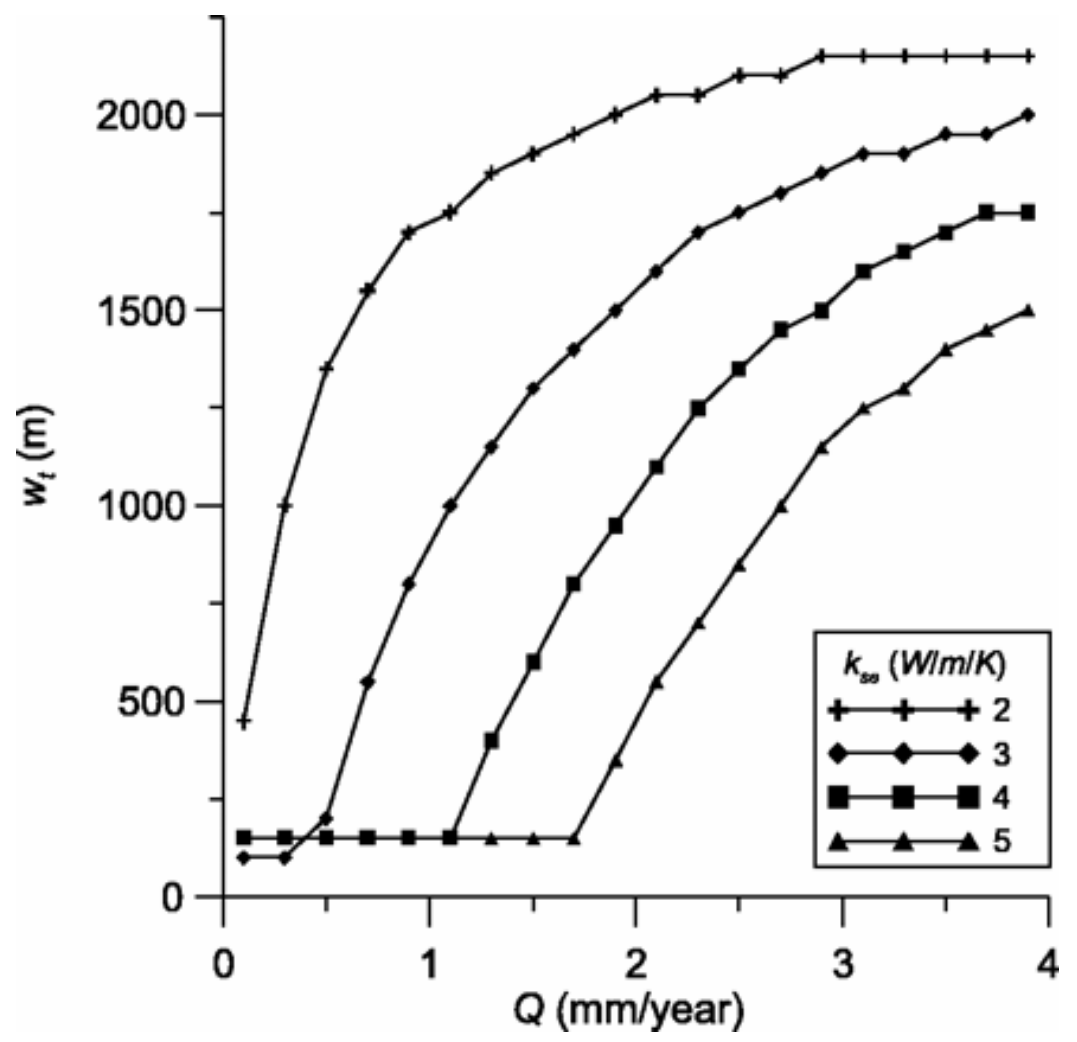

Fig. 7. Top thermal aureole thickness $w_{t}$, defined as the thickness of country rock heated above $400^{\circ} \mathrm{C}$, as a function of the magma emplacement rate $Q$, for different sediment conductivities $k_{s e}$. The total accumulated granite thickness is $5 \mathrm{~km}$; the granite top is at $10 \mathrm{~km}$, the sill thickness is $50 \mathrm{~m}$, the granite conductivity is $3 \mathrm{~W} / \mathrm{m} / \mathrm{K}$, the HHC conductivity is $2 \mathrm{~W} / \mathrm{m} / \mathrm{K}$, and the initial geothermal gradient is linear with HHC-sediment interface temperature $T_{i}=$ $300^{\circ} \mathrm{C}$. Here $w_{t}$ is calculated with a precision of $50 \mathrm{~m}$, which is why the curves are not smooth.

Figure 7 shows the width of the thermal aureole, $w_{t}$, in the granite overlying sediments for a granite roof at $10 \mathrm{~km}$ and sill thickness of $50 \mathrm{~m}$, for a total granite thickness of $5 \mathrm{~km}$. Note that in Fig. 7, part of the results involves emplacement rates that are above the critical emplacement rate for convection as discussed above. As our model of heat transfer is conductive only, the aureole thicknesses shown in Fig. 7 are minimum values. For most emplacement rates and country rock conductivities investigated, the thickness of the thermal aureole depends on both of those parameters (Fig. 7). For instance, at an emplacement rate of $1 \mathrm{~mm} / \mathrm{year}$, any sediment conductivity lower than $4 \mathrm{~W} / \mathrm{m} / \mathrm{K}$ yields an 
aureole thickness of at least $1 \mathrm{~km}$. However, there is a domain at low emplacement rates and/or high country rock conductivities, where the aureole thickness is nearly independent of emplacement rate and only depends slightly on conductivities (Fig. 7). Under such conditions, heat is conducted away through the rocks overlying the granite sufficiently rapidly to balance the heat advected by magma input and conducted through the formerly emplaced granite pile. We define a critical emplacement rate, $Q_{a}$, for the growth of the thermal aureole. Below $Q_{a}$, the thermal aureole reaches its maximum thickness after the first sill emplacement, and its size depends on the individual sill thickness (Fig. 8) and not on the total thickness of granite. $Q_{a}$ is strongly dependent on country rock conductivity (Fig. 9). $Q_{a}$ is smaller than $Q_{c}$, the critical emplacement rate for convection (Fig. 6). Whatever the initial temperature, the system tends toward an equilibrium geothermal gradient and $Q_{a}$ can be higher if the equilibrium temperature at the granite emplacement depth is low. The equilibrium temperature in the system is controlled by the $\mathrm{HHC}$, granite and sediment conductivities, and by the emplacement depth of the granite (Fig. 4). Thus, high values of $Q_{a}$ are favoured by shallow emplacement depth, low $\mathrm{HHC}$ conductivities and high overlying sediment conductivities (Fig. 9). Figure 4 shows that there is a domain at high HHC conductivities, and low sediment conductivities, where the equilibrium temperature is above $400^{\circ} \mathrm{C}$. In this domain, the thermal aureole cannot remain thin.

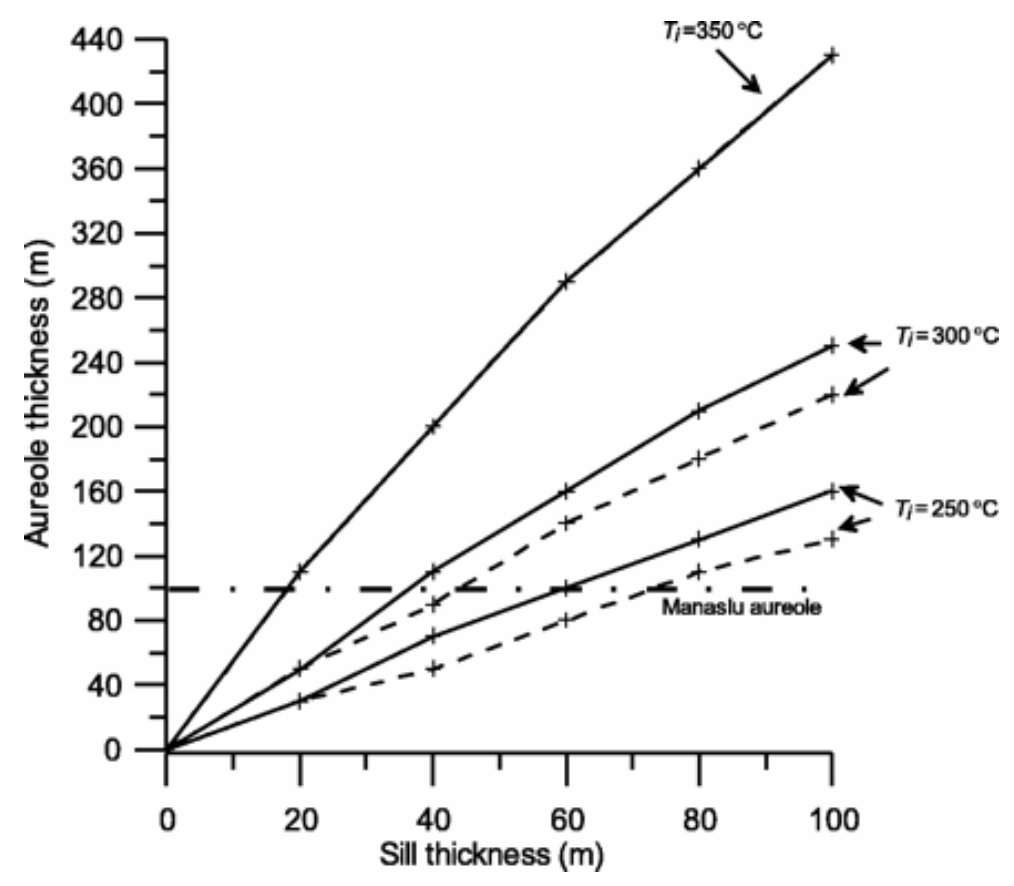

Fig. 8. The thermal aureole thickness for conditions below the critical emplacement rate, as a function of sill thickness for different $\mathrm{HHC}$-sediment interface temperatures $T_{i}$. Continuous lines: the latent heat of sediment metamorphism is neglected; dashed lines: the sediment latent heat of metamorphism is $600 \mathrm{~J} / \mathrm{kg} / \mathrm{K}$ between $400^{\circ} \mathrm{C}$ and $600^{\circ} \mathrm{C}(\mathrm{Furlong}$ et al., 1991). HHC and sediment conductivities are 2 and $3.5 \mathrm{~W} / \mathrm{m} / \mathrm{K}$ respectively. The horizontal dot-dashed line marks the maximum aureole thickness overlying the Manaslu leucogranite. The aureole thickness is calculated with a precision of $5 \mathrm{~m}$. 


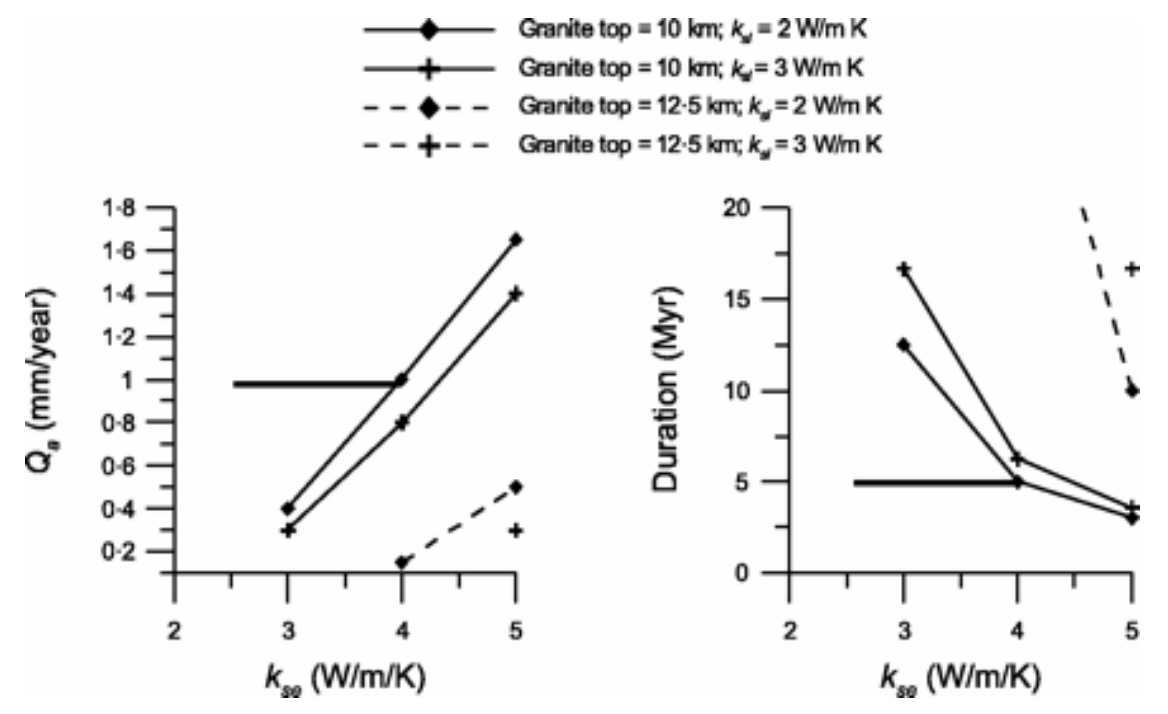

Fig. 9. Critical emplacement rate $Q_{a}$ limiting the aureole growth and corresponding emplacement duration for different sediment conductivities $k_{s e}, \mathrm{HHC}$ conductivities $k_{s}$, and initial HHC-sediment interface depths. The bold horizontal line marks the range of realistic sediment conductivities and the Manaslu emplacement rate or duration inferred from geochronological data (Harrison et al., 1999b). These results are for a leucogranite injection temperature of $780^{\circ} \mathrm{C}$. The maximum difference in $Q_{a}$ for an injection temperature of $750^{\circ} \mathrm{C}$ is $0.2 \mathrm{~mm} / \mathrm{year}$.

We found that for $Q_{a}$ to be above $0.1 \mathrm{~mm} /$ year (the lowest tested emplacement rate), the magma injection depth must be $<15 \mathrm{~km}$. For emplacement at $12.5 \mathrm{~km}$ depth, critical emplacement rates of more than $0.1 \mathrm{~mm} /$ year are possible, but require unrealistically high sediment conductivities. For $10 \mathrm{~km}$ depth and for sediment conductivities in the range $3-4 \mathrm{~W} / \mathrm{m} / \mathrm{K}$, it is possible to build a $5 \mathrm{~km}$ thick lens with a corresponding small contact aureole (Fig. 9). For this range of sediment conductivity, greater depths of intrusion increase the period of pluton growth to at least $10 \mathrm{Myr}$, i.e. significantly beyond the geochronologically constrained interval of 5 Myr. Below $Q_{a}$, the aureole thickness is two to six times the sill thickness, depending on the initial crustal temperature (Fig. 8). Our computation suggests that to form a thermal aureole less than $100 \mathrm{~m}$ thick, the typical sill thickness should be $<60 \mathrm{~m}$, which is about the scale-length of the $\mathrm{Rb}-\mathrm{Sr}$ heterogeneity at Manaslu (Deniel et al., 1987).

We have computed the temperature in the country rock at every $1 \mathrm{~m}$ over a distance to the contact of $50 \mathrm{~m}$. The thermal aureole peak temperature is a maximum at the contact with the granite and decreases further away (Fig. 10). The slope of this temperature decrease is steeper with thin sills. Below $Q_{a}$, the aureole peak temperature is not sensitive to the country rock conductivity, or to the injection depth, but depends on the initial country rock temperature, magma temperature and the sill thickness (Fig. 11). Our results suggest that the peak temperature of $550 \pm 40^{\circ} \mathrm{C}$ inferred from thermobarometric studies on the Manaslu top aureole (Guillot et al., 1995a) is consistent with an initial country rock temperature at the onset of injection of no more than $300^{\circ} \mathrm{C}$, in agreement with previous estimates (Copeland et al., 1990), and a sill thickness of $<50 \mathrm{~m}$. 


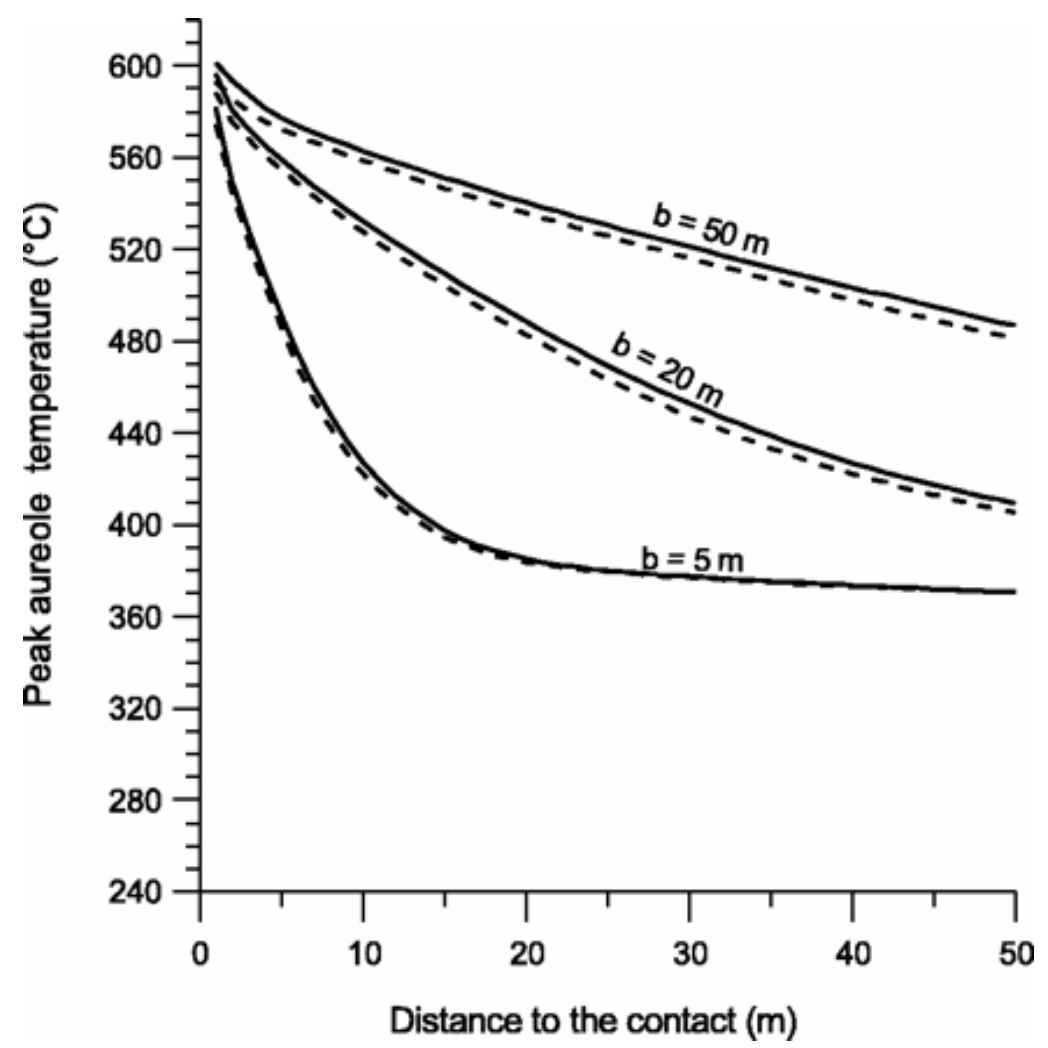

Fig. 10. Profiles of the peak temperature in the top thermal aureole as a function of distance to the contact, for different sill thickness $b$, for injection temperatures of $780^{\circ} \mathrm{C}$ (continuous lines) and $750^{\circ} \mathrm{C}$ (dashed lines). The sediment latent heat of metamorphism is $600 \mathrm{~J} / \mathrm{kg} / \mathrm{K}$ between $400^{\circ} \mathrm{C}$ and $600^{\circ} \mathrm{C}$ (Furlong et al., 1991). Initial temperature $T_{i}$ is $250^{\circ} \mathrm{C}$, emplacement depth is $10 \mathrm{~km}, K_{s e}$ is $3.5 \mathrm{~W} / \mathrm{m} / \mathrm{K}$, emplacement rate is below $Q_{a}(0.5$ $\mathrm{mm} /$ year).

(a)

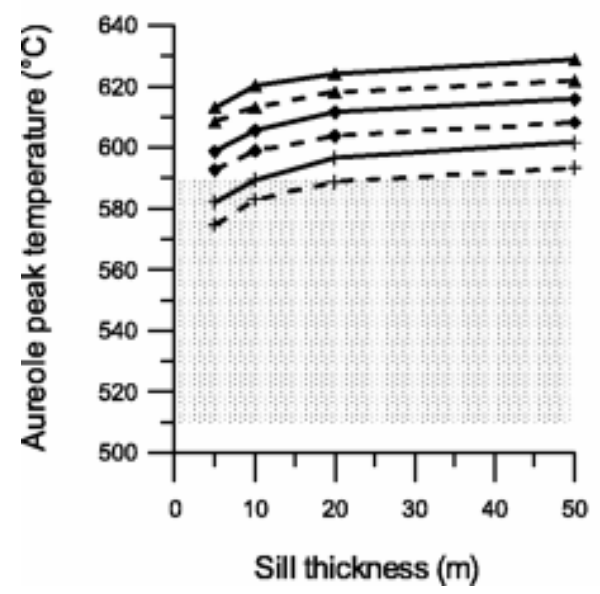

(b)

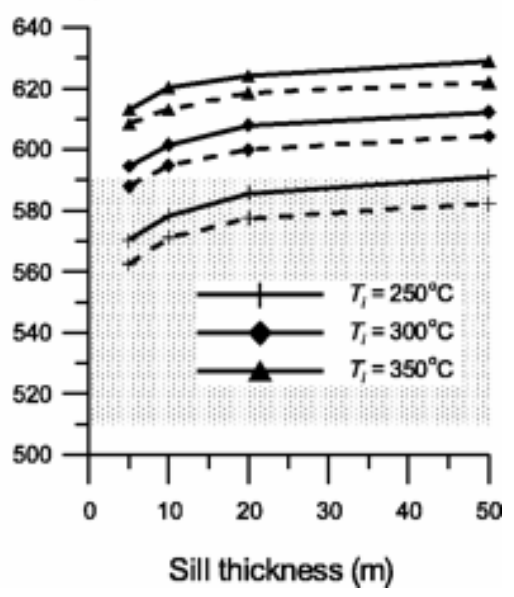

Fig. 11. Peak temperatures in the sediments at distance of $1 \mathrm{~m}$ from the granite contact for different sill thickness and $T_{i}$. (a) The latent heat of sediment metamorphism is neglected. (b) The sediment latent heat of metamorphism is 600 $\mathrm{J} / \mathrm{kg} / \mathrm{K}$ between $400^{\circ} \mathrm{C}$ and $600^{\circ} \mathrm{C}$ (Furlong et al., 1991). The emplacement rate is below $Q_{a}(0.5 \mathrm{~mm} /$ year). The continuous lines are for a sill intrusion temperature of $780^{\circ} \mathrm{C}$, the dashed lines are for a sill intrusion temperature of $750^{\circ} \mathrm{C}$. The peak temperatures range inferred from thermobarometry (Guillot et al., 1995) is shown by the grey shaded area. 
Tectonic

A tectonic top contact implies that the thermal aureole thickness is not a relevant constraint on the emplacement rate because of the renewal of the country rock. We modelled the process of tectonic unroofing by keeping the roof temperature, $T_{i}$, constant during emplacement as a consequence of fault movement. In this model, the maximum emplacement rate for $5 \mathrm{~km}$ of leucogranite to emplace without onset of large-scale convection, $Q_{c}$, is independent of the overlying sediment conductivity. $Q_{c}$ depends on $T_{i}$ and not on the emplacement depth. As expected, $Q_{c}$ is higher than in the case of a statically heating roof (Fig. 12).
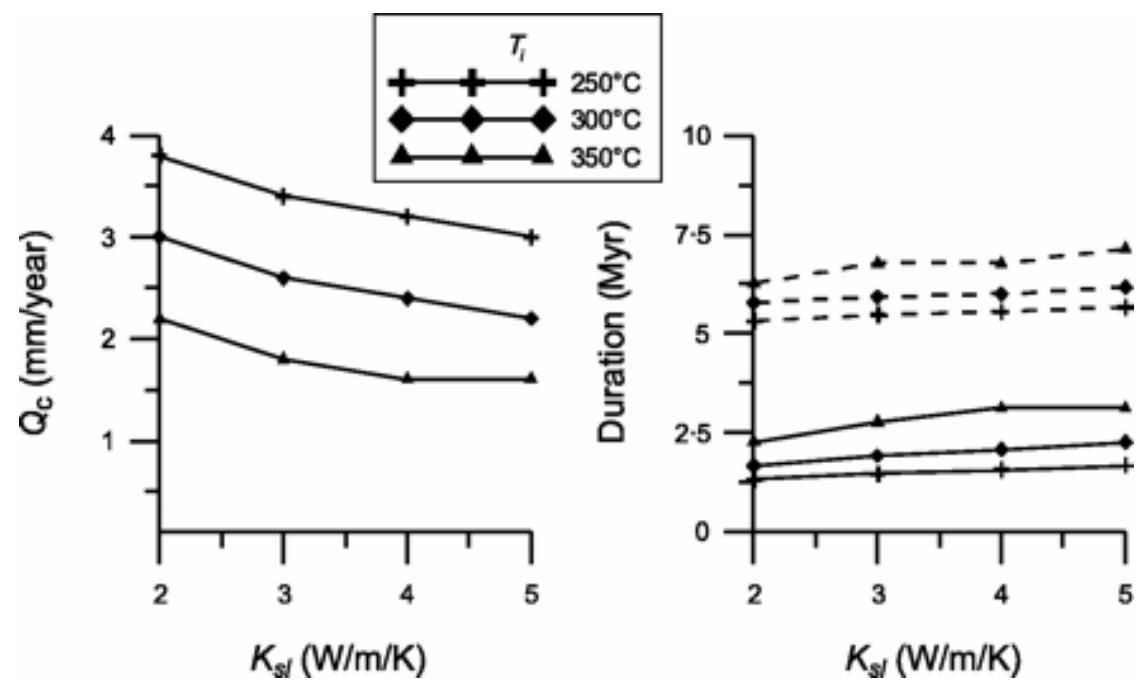

Fig. 12. Critical emplacement rate for convection $Q_{c}$ and total emplacement duration, corresponding to a critical granite thickness of $5 \mathrm{~km}$, in the case of unroofing, for different HHC conductivities $k_{s}$, and temperatures $T_{i}$. The sediment temperature at the granite contact is kept constant and equal to $T_{i}$. $Q_{c}$ with or without a repose period is the same. In the case of a repose period, the duration of the repose period must be added to the total duration time (dashed lines).

$Q_{c}$ is about the same, with or without a repose period; thus, allowing for the repose period adds only $4 \mathrm{Myr}$ to the total emplacement time (Fig. 12). The highest $Q_{c}$ is 3.4 $\mathrm{mm} /$ year with $T_{i}=250^{\circ} \mathrm{C}$. In this latter case, the Manaslu granite could have been emplaced in 1.3 Myr if its emplacement was not interrupted. In the case of a $4 \mathrm{Myr}$ repose period, the total duration is at least $5.3 \mathrm{Myr}$.

\section{Thermal}

effects

of

HHL

intrusion

Figure 13a shows the temperature profile in the crust after the emplacement of $5 \mathrm{~km}$ of granite between 10 and $15 \mathrm{~km}$ depth at a rate of $1 \mathrm{~mm} /$ year. The case for tectonic unroofing is shown in Fig. 13b. In the case of tectonic unroofing, the emplacement level is deeper $(12.5 \mathrm{~km})$ and the emplacement rate is higher $(2.5 \mathrm{~mm} / \mathrm{year})$. However, because the constraints of no large-scale convection apply in both cases, the maximum temperatures allowed in the granite body and the bottom contact temperature are the same. In the $\mathrm{HHC}$, close to the bottom granite contact, the temperature reaches $700^{\circ} \mathrm{C}$ when the magma is intruded. However, this peak in temperature is transient and 
restricted to a few tens of metres close to the contact. On a larger scale, the $\mathrm{HHC}$ temperature equilibrates at $600^{\circ} \mathrm{C}$ in the proximity of the granite (Fig. 13). Under the lithostatic pressure at $15 \mathrm{~km}$ depth and below (pressure $>4 \mathrm{kbar}$ ), this temperature is below the metapelite solidus temperature (Clemens \& Vielzeuf, 1987; Patiño Douce \& Harris, 1998). The dehydration melting temperature of pelites (about $700^{\circ} \mathrm{C}$ ) is reached more than $8 \mathrm{~km}$ below the granite bottom contact. Thus, our results suggest that the increase in migmatization toward the thickest HHL cannot be the effect of HHL cooling.
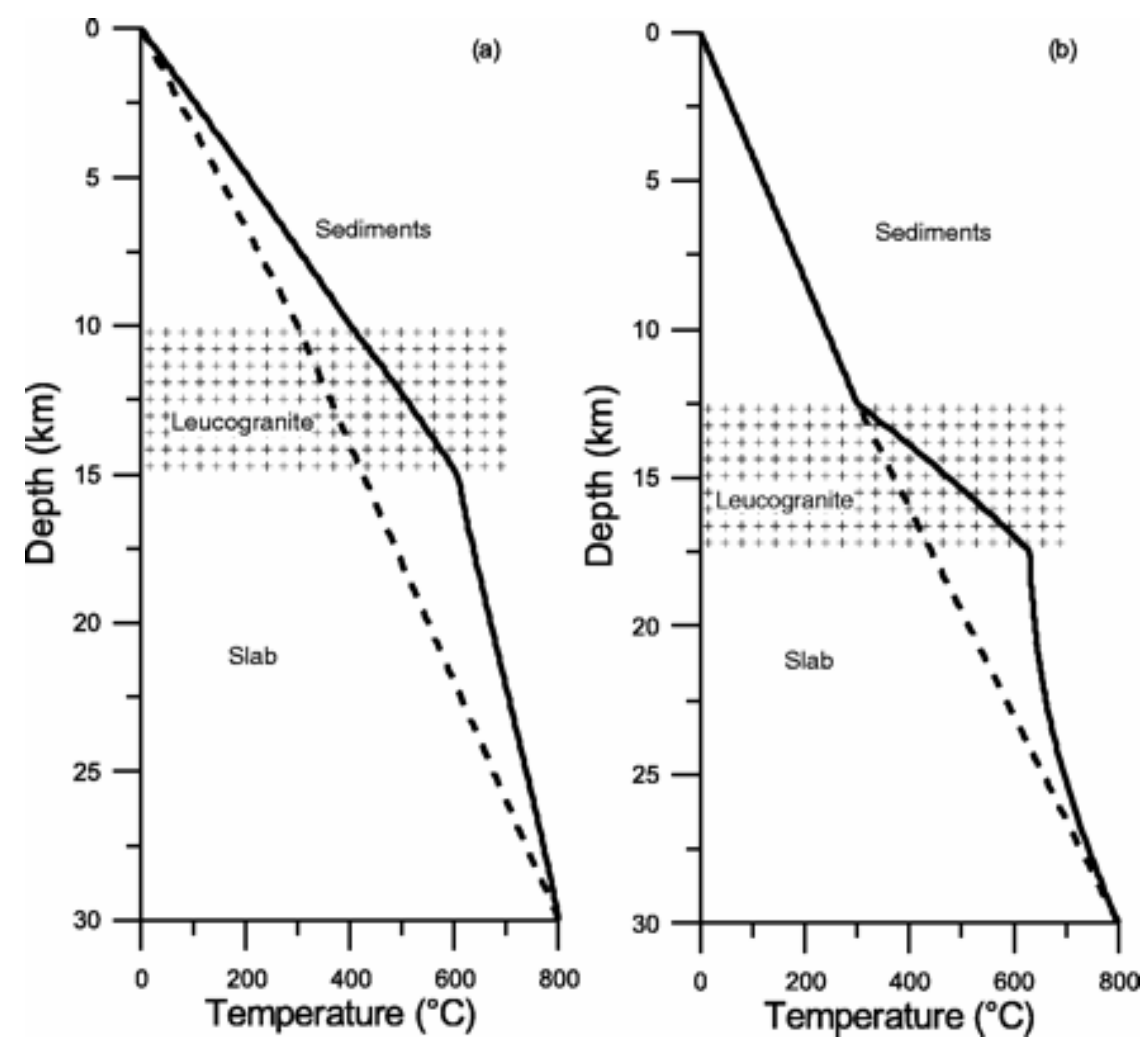

Fig. 13. Profiles of crustal temperature after the emplacement of $5 \mathrm{~km}$ of leucogranite at a rate close to $Q_{a}$ (continuous line). The dashed line shows the initial geothermal gradient. (a) The leucogranite roof is allowed to heat; depth of emplacement is $10 \mathrm{~km}, Q$ is $1 \mathrm{~mm} / \mathrm{year}$, and the sediment conductivity is $4 \mathrm{~W} / \mathrm{m} / \mathrm{K}$. (b) The roof of the leucogranite is at a fixed temperature of $250^{\circ} \mathrm{C}$ (unroofing case); the emplacement depth is $12.5 \mathrm{~km}, Q$ is $2.5 \mathrm{~mm} /$ year. Sills are $15 \mathrm{~m}$ thick and the HHC conductivity is $2 \mathrm{~W} / \mathrm{m} / \mathrm{K}$ in both (a) and (b).

Cooling

of

the

leucogranite

The temperature evolution at depths of 10,11 and $12.5 \mathrm{~km}$ during the emplacement of the granite and until 3 Myr after the end of intrusion is plotted in Fig. 14. 


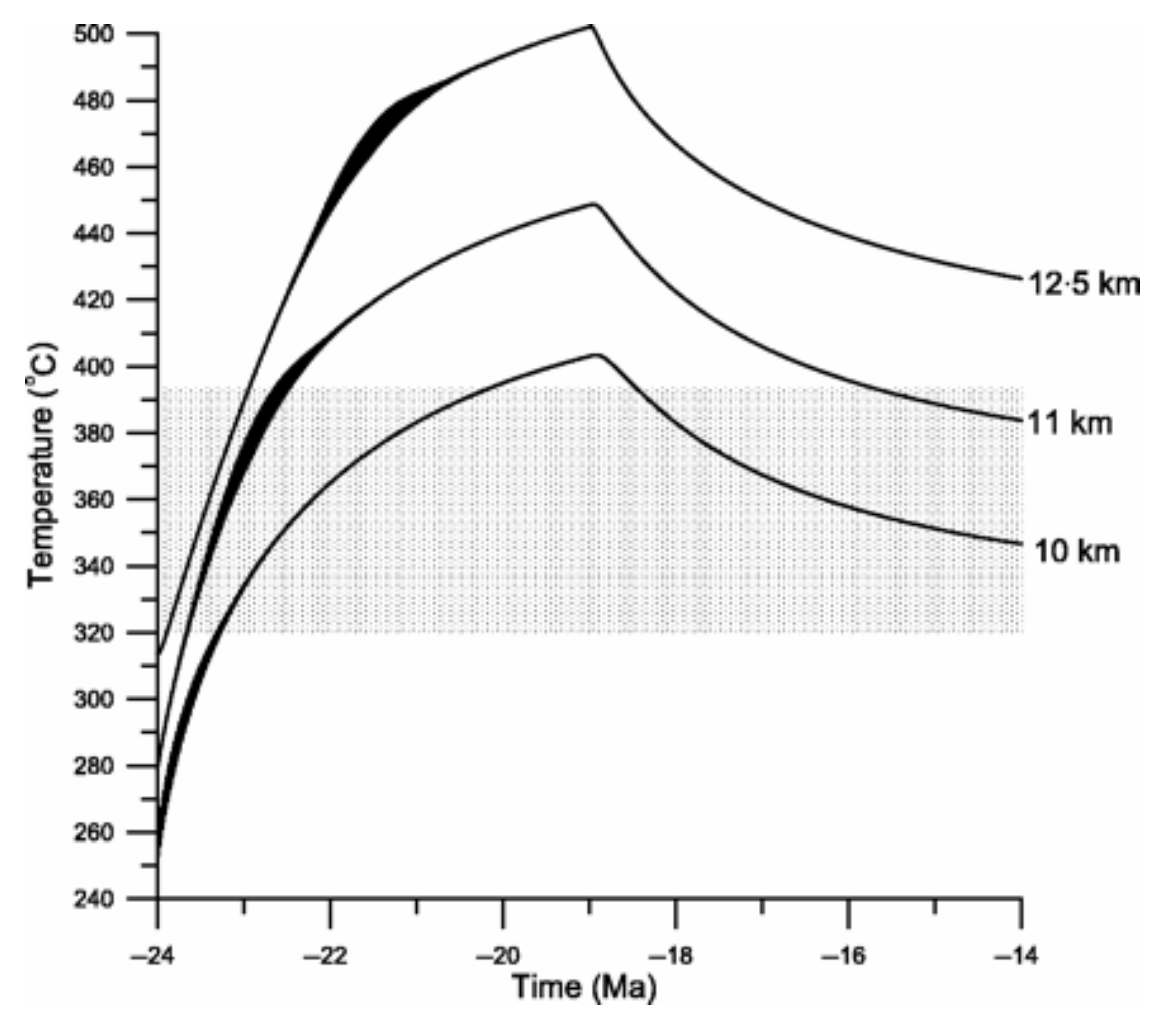

Fig. 14. Temperature evolution in the system at 10, 11 and $12.5 \mathrm{~km}$ depth. The leucogranite intrusion starts at $24 \mathrm{Ma}$ and stops at $19 \mathrm{Ma}$ according to geochronological data (Harrison et al., 1999b). The curve for $10 \mathrm{~km}$ corresponds to the temperature evolution of the first emplaced sill. The apparent thickening of the curves is due to temperature oscillations corresponding to sill emplacement at or close to the plotted level. The magma is injected at $750^{\circ} \mathrm{C}$ with an emplacement rate of $1 \mathrm{~mm} /$ year. The grey shaded area represents the closure temperature of muscovite.

The leucogranitic body extends from 10 to $15 \mathrm{~km}$. We assumed here that the first sill was injected at $24 \mathrm{Ma}$ at an emplacement rate of $1 \mathrm{~mm} / \mathrm{year}$ and that intrusion stopped at 19 $\mathrm{Ma}$. The temperature evolution at $10 \mathrm{~km}$ depth corresponds to the temperature evolution of the first emplaced sill. The thickening of the 10 and $12.5 \mathrm{~km}$ curves at 23 and $21.5 \mathrm{Ma}$, respectively, corresponds to temperature oscillation because of the injection of sills at or close to this level.

The $\mathrm{Ar}^{40}-\mathrm{Ar}^{39}$ data for the top of Manuslu granite indicate a closure age of muscovite in the range of $17.1 \pm 0.1$ to $18.4 \pm 0.1 \mathrm{Ma}$ (Copeland et al., 1990), suggesting that the upper part of the granite cooled below $357 \pm 38^{\circ} \mathrm{C}, 1-2 \mathrm{Myr}$ after the end of intrusion. The temperatures we computed for the top of the granite are in good agreement with the $\mathrm{Ar}-\mathrm{Ar}$ data. For the lower part of the body, Ar-Ar ages range from 14.7 \pm 0.2 to $16.6 \pm$ $0.1 \mathrm{Ma}$. At this time, our computed temperatures at $12.5 \mathrm{~km}$ depth, in the middle of the body, are above the muscovite closure temperature (Fig. 14). This discrepancy can be explained if the granite emplacement rate was less than the modelled rate of $1 \mathrm{~mm} /$ year, or if granite cooling was accelerated by the post-emplacement slip of the STD. 


\title{
DISCUSSION
}

\begin{abstract}
The emplacement of the Manaslu granite
Heat transfer modelling provides constraints on the upper limit of emplacement rates for the HHL. Geochronological data suggest that the emplacement of the Manaslu intrusion took place over no more than 5-6 Myr. If the intrusion rate was steady, then these data suggest that the intrusion rate could not have been lower than $1 \mathrm{~mm} /$ year. Our modelling suggests that many parameter ranges, consistent with the observations of no convection and a thin thermal aureole, fall below this lower limit. However, model results with shallow emplacement (roof at $10 \mathrm{~km}$ ) are at, or above, $1 \mathrm{~mm} / y e a r$, and are, therefore, consistent with the geochronological data. The thickness and temperature of the Manaslu thermal aureole can be explained by the intrusion of sills 20-60 m thick, in broad agreement with the size of individual magma batches inferred from $\mathrm{Rb}-\mathrm{Sr}$ systematics (Deniel et al., 1987). A $1 \mathrm{~mm} / \mathrm{year}$ emplacement rate implies that the average time interval between injections was of the order of 20 000-60 000 years. Two magma pulses separated by a repose period of $4 \mathrm{Myr}$, as proposed by Harrison et al. (1999b), permit a higher emplacement rate for each pulse. However, when the repose time is included in the total emplacement duration, this duration is more than 5 Myr. Thus, a better fit between the thermal results and the geochronological data is found with a continuous emplacement, rather than with a repose period.
\end{abstract}

If the top contact is not tectonic, for the leucogranite to avoid large-scale convection and thermal aureole growth, the model requires the $\mathrm{HHC}$ conductivity to be lower than that of the sediments, in contrast to the conclusions of Jaupart \& Provost (1985) and Pinet \& Jaupart (1987). Those workers proposed a model of heat refraction at a high conductivity HHC-low conductivity sediment interface; heat focusing causes partial melting at this interface. Such an approach assumes that melt generation and leucogranite emplacement have occurred at the same crustal level, as it seems to have done along some transects such as in the Everest-Makalu area (Visona \& Lombardo, 2002; Searle et al., 2003). However, in order to avoid convection, in situ models are constrained to produce $\mathrm{HHL}$ at small rates and to allow the first-intruded magma layer to cool before the next sill is intruded. The latter condition seems particularly difficult to realize, as melting driven by thermal refraction is likely to be a continuous process, and the melt fraction should increase with time. We conclude that such models, although conceptually viable, are not applicable to the HHL whenever they exhibit isotopic heterogeneities.

Because of the slow accretion rate, the amount of heat available at any time at the intrusion locus to establish a hydrothermal convective system is small. Stable isotope studies on the Manaslu granite (France-Lanord et al., 1988) also indicate that there has not been any large-scale hydrothermal interaction of the granite with meteoric water. 
Were HHL intrusion and STD motion coeval?

If the upper contact is tectonic in origin, then the existence of a thin aureole is not a constraint; high emplacement rates become feasible even for an emplacement level between 15 and $20 \mathrm{~km}$. We note, however, that everywhere in the Himalaya, the HHL contain magmatic muscovite, which restricts pressure to above $\sim 2.8$ kbar during crystallization. This does not preclude that solidified parts of the granite went outside the muscovite stability field during pluton growth, but it does imply that its molten parts remained in the $P-T$ field of muscovite crystallization. This suggests that pressure conditions remained more or less constant during the intrusive stage, at least at the locus of magma intrusion. If initial intrusion was at 3-4 kbar, then motion on the STD cannot have been extensive during most of the period of pluton growth. For a pluton emplaced at deeper levels, the possibility of STD slip during laccolith growth can be evaluated using the simple model illustrated in Fig. 15, where a pluton intruded at a depth of $15 \mathrm{~km}$ is intersected by the STD, which dips north at an angle of $30^{\circ}$, although we note that the dip angle of the STD can be lower (e.g. Burchfiel et al., 1992). Assuming a slip rate on the STD of $20 \mathrm{~mm} /$ year (Dèzes et al., 1999; Harrison et al., 1999a), and that muscovite cannot crystallize in the HHL at depths shallower than $\sim 10$ $\mathrm{km}$, then the geometrical relationships show that it would take $0.5 \mathrm{Myr}$ for the pluton to rise to a depth of $10 \mathrm{~km}$ by fault slip alone (see Fig. 15 caption).

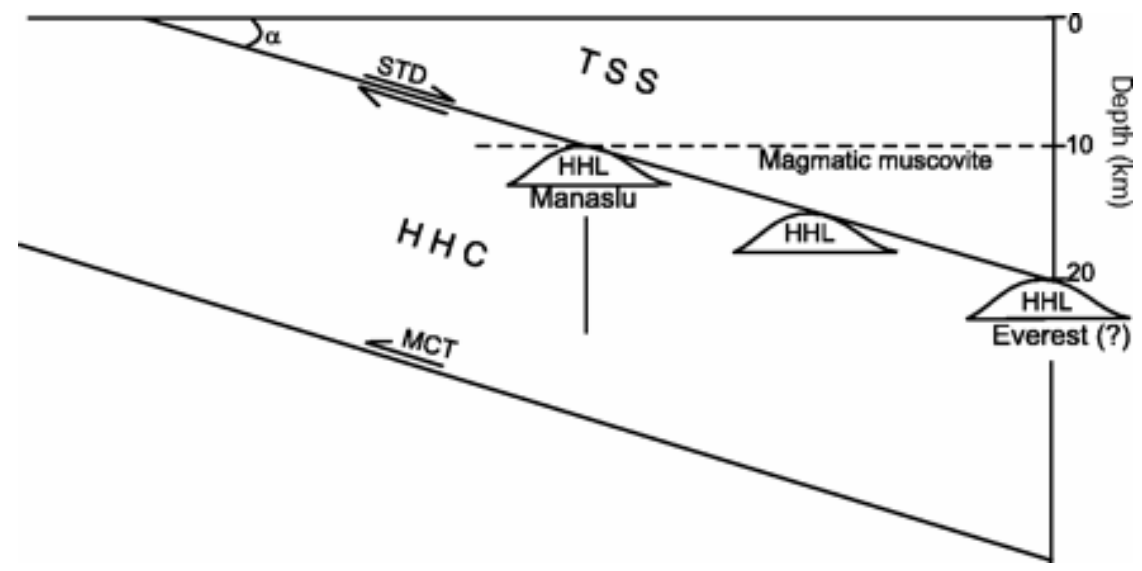

Fig. 15. Schematic N-S cross-section showing the geometrical relationships between the HHL plutons and the South Tibetan Detachment (STD), assuming that intrusion and extension processes were coeval. TSS is the Tethyan Sedimentary Series, HHC is Higher Himalayan Crystallines, MCT the Main Central Thrust. The dashed horizontal line marks the upper possible limit for magmatic crystallization in the $\mathrm{HHL}$. Three possibilities of $\mathrm{HHL}$ emplacement are shown: the shallowest corresponds to the Manaslu, whereas the deepest could correspond to intrusives in the Everest-Makalu area. Depending on the dip angle $(\alpha)$ of the STD and on the slip rate along the STD, the time allowed for pluton intrusion to reach the limiting pressure below which no muscovite can crystallize in the HHL, owing to STD slip, may vary along strike. This time $t$ (in years) is given by the equation $t=[(D-10) / \sin (\alpha)] /\left(V \times 10^{-6}\right)$ where $V$ is the slip rate in $\mathrm{mm} / \mathrm{year}$ and $D$ is the intrusion starting depth in $\mathrm{km}$.

Starting at $20 \mathrm{~km}$ depth, with the same dip angle and slip rate, gives a duration of $1 \mathrm{Myr}$ to unroof the granite from 20 to $10 \mathrm{~km}$, which is about the time required to intrude $5 \mathrm{~km}$ of leucogranite. However, both the dip angle and the slip rate of the STD are likely to vary along strike; thus, these estimates are only indications. If tectonic unroofing indeed took place during $\mathrm{HHL}$ intrusion and crystallization, then it requires a slip rate $<20$ 
$\mathrm{mm} /$ year and a dip angle no higher than $30^{\circ}$ such that none of the HHL so far documented along the $2500 \mathrm{~km}$ strike of the Himalaya range reached a depth shallower than $10 \mathrm{~km}$ while still molten. Because deformation related to the STD has demonstrably affected the HHL once crystallized (Burg et al., 1984; Searle et al., 1997), the timing of STD slip during and after HHL intrusion should have followed a precise temporal pattern so as to allow first magmatic crystallization of muscovite and then subsolidus deformation. A detailed study of the possible effects of extensional fault activity on the cooling of the HHL is presented elsewhere (Annen \& Scaillet, in preparation).

An observation that argues against a close relationship between active magmatism and extensional faulting is that the deformation related to the STD is concentrated above and not within the HHL. If the STD was active during HHL emplacement, then we would expect that each newly injected thin sill would act as a preferential décollement layer, as it represents the weakest rheological level of the deforming upper pile (Davidson et al., 1994). The very fact that the largest HHL have mostly isotropic magmatic fabrics strongly suggests that, for the most part, they were fully crystallized when STD motion started, acting as rigid objects, and that deformation was concentrated above them in the more ductile sedimentary layers. This view is supported by the fact that, at least at Manaslu, the barometric difference between the top and bottom contact of the intrusion fits with the present-day structural thickness (Guillot et al., 1995a), implying that the entire body has not been significantly shortened or thinned by regional deformation. This does not preclude the possibility that smaller intrusions could have been actively deformed while partly liquid, as observed in some instances (Dèzes et al., 1999; Murphy \& Harrison, 1999) and, in fact, the protracted time interval of HHL crystallization documented at many places along the range (Coleman, 1998) offers room for small, late-stage, intrusive stocks to be affected by the STD. However, the field evidence argues against the idea that the main phase of extension was coeval with the main phase of Manaslu intrusion. In particular, Guillot et al. (1993) reported the Manaslu granite as cross-cutting the Naïke fold-a large anticline structure that they related to the first phase of extensional tectonics having affected this area. We thus contend that Manaslu intrusion probably occurred before the main phase of STD slip. We recognize, however, that the timing constraints suggest STD motion immediately after the main phase of HHL intrusion.

\section{Implications}

for

magma

production

The zircon and monazite saturation systematics of the HHL show that the residence time of the parental anatectic melts in their source was short, of the order of a few thousand years, and certainly shorter than 50000 years (Ayres et al., 1997). This agrees well with our model results of thin sills intruded at intervals of $20000-60000$ years. For a given emplacement rate, thicker sills require a longer time interval between melt injections. Short residence times suggest that whatever the physical processes of melt extraction and collection from the source, these are not the rate-limiting factors of pluton growth (Harris et al., 2000). Similarly, rates of magma ascent through the dyke network are expected to be geologically instantaneous (Scaillet et al., 1996), and cannot be the controlling parameter of long-term intrusion rates. As explained in the Introduction, in the Himalaya range, the main heat source was internal radioactive decay following crustal thickening, perhaps helped by frictional heating along large thrust faults (England et al., 
1992; Harrison et al., 1998). Previous thermal modelling has shown that the time-scale of thermal excursion of thickened crust into the melting range $\left(>650^{\circ} \mathrm{C}\right)$ is of the order of 10-20 Myr, or more, depending on erosion-decompression rates (England \& Thompson, 1984), in broad agreement with our findings for the time needed for the upper crustal assembly of anatectic melts into sizeable plutonic bodies. We thus conclude that melt availability for pluton growth is fundamentally controlled by the rate of heat supply into the protoliths-a conclusion also reached by Harris et al. (2000). Thus, although the very process of magma ascent within the crust can be very fast, the integrated time to build a pluton of batholitic dimensions in collisional orogens with no mantle supply is several Myr.

\section{CONCLUSIONS}

We have shown that it is possible to emplace a thick magma body in the upper crust that has a rather limited thermal effect on its surroundings (i.e. a small contact aureole one order of magnitude smaller than the thickness of pluton). Our results indicate that for an igneous body with a thickness of several kilometres, the absence of convection and presence of a narrow thermal aureole can be explained by the slow accretion of separate magma batches, injected as thin sills.

Application of our data to the Manaslu pluton shows that, with the most conservative assumptions, the maximum emplacement rate of this pluton was $3.4 \mathrm{~mm} / \mathrm{year}$ if unroofing was active during emplacement, and $1 \mathrm{~mm} / \mathrm{year}$ if no unroofing took place. First-order geological observations, however, seem to preclude strict contemporaneity between STD slip and HHL intrusion, and thus our preferred scenario is that intrusion of the HHL occurred before the main phase of extensional tectonics. In such a case, the best fit with available geochronological data, which suggest an emplacement duration of $5 \mathrm{Myr}$, and geochemical and thermobarometric constraints, is found for 20-60 m thick sills emplaced at relatively shallow depth (granite roof at about $10 \mathrm{~km}$ ) in a crust with an initial temperature of no more than $300^{\circ} \mathrm{C}$. A steady emplacement rate is in better agreement with the geochronological data than several short magma pulses separated by long repose periods. The results agree with the view that the time-scales of emplacement of the granite at shallow level are commensurate with the time-scale of melt generation at depth. In collisional settings with no mantle contribution, melt production and pluton emplacement must take place over several million years-a view that contrasts with recent proposals that most granitic plutons are emplaced in less than 100000 years, irrespective of tectonic setting (Petford et al., 2000^). From the perspective of the mechanisms of exhumation of deep-seated crustal rocks in collisional ranges, the available data at Manaslu do not support the idea that the MCT and the STD were strictly synchronous in this area, but instead suggest that STD initiated after crystallization of the pluton emplacement. Future work is needed to evaluate whether such diachronicity is specific to Manaslu or applies to other HHL and, if so, to explore to what extent this diachronicity is compatible with the concept of crustal channel flow as currently envisioned for the Himalayas. 


\section{ACKNOWLEDGEMENTS}

We thank Lukas Baumgartner for stimulating discussions on thermal aureoles. The paper greatly benefited from the helpful reviews of Ste'phane Guillot, Nigel Harris and George Bergantz, as well as from the careful editorial handling of Marjorie Wilson. The research was funded by a Swiss National Science Foundation grant (8220-064666) and by an Ernst and Lucie Schmidheiny grant to C.A. and by a Royal Society Wolfson Merit Award to R.S.J.S.

\section{REFERENCES}

Ayres, M. \& Harris, N. (1997). REE fractionation and Nd-isotope disequilibrium during crustal anatexis: constraints from Himalayan leucogranites. Chemical Geology 139, 249-269.

Ayres, M. W., Harris, N. B. W. \& Vance, D. (1997). Possible constraints on anatectic melt residence times from accessory mineral dissolution rates: an example from Himalayan leucogranites. Mineralogical Magazine 61, 29-36.

Barbey, P., Brouand, M., Le Fort, P. \& Pecher, A. (1996). Granite-migmatite genetic link: the example of the Manaslu granite and Tibetan Slab migmatites in central Nepal. Lithos 38, 63-79.

Beaumont, C., Jamieson, R. A., Nguyen, M. H. \& Lee, B. (2001). Himalayan tectonics explained by extrusion of a low-viscosity crustal channel coupled to focused surface denudation. Nature 414, 738-742.

Beaumont, C., Jamieson, R. A., Nguyen, M. H. \& Medvedev, S. (2004). Crustal channel flows: 1. Numerical models with applications to the tectonics of the Himalayan-Tibetan orogen. Journal of Geophysical Research 109, Art. No. B06406.

Benard, F., Moutou, P. \& Pichavant, M. (1985). Phase relations of tourmaline leucogranites and the significance of tourmaline in silicic magmas. Journal of Geology 93, 271-291.

Bergantz, W. (1989). Underplating and partial melting: implications for melt generation and extraction. Science 245, 1093-1095.

Bergantz, G. W. \& Dawes, R. (1994). Aspects of magma generation and ascent in continental lithosphere. In: Ryan, M. P. (ed.) Magmatic Systems. San Diego, CA: Academic Press, pp. 291-317. 
Brown, L. D., Zhao, W. J., Nelson, D. K., Hauck, M., Alsdorf, D., Ross, A., et al. (1996). Bright spots, structure, and magmatism in southern Tibet from INDEPTH seismic reflection profiling. Science $274,1688-1690$.

Burchfiel, B. C., Zhiliang, C., Hodges, K. V., Yuping, L., Royden, L. H., Changron, D. \& Jiene, X. (1992). The South Tibetan Detachment System, Himalayan Orogen. Geological Society of America Special Paper 269, 41 pp.

Burg, J. P., Brunel, M., Gapais, D., Chen, G. M. \& Liu, G. H. (1984). Deformation of leucogranites of the crystalline Main Central Sheet in southern Tibet (China). Journal of Structural Geology 6, 535-542.

Caby, R., Pecher, A. \& Le Fort, P. (1983). Le grand chevauchement central himalayen: nouvelles donne'es sur le me'tamorphisme inverse à la base de la Dalle du Tibet. Revue de Géologie Dynamique et de Géographie Physique 24, 89-100.

Chapman, D. S. \& Furlong, K. P. (1992). Thermal state of the continental lower crust. In: Fountain, D. M., Arculus, R.\&Kay, R. W. (eds) Continental Lower Crust. Developments in Geotectonics 23, 179-199.

Clauser, C. \& Huenges, E. (1995). Thermal conductivity of rocks and minerals. In: Ahrens, T. J. (ed.) Rock Physics and Phase Relations: A Handbook of Physical Constants. Washington, DC: AGU Reference Shelf, pp. 105-126.

Clemens, J. D. \& Vielzeuf, D. (1987). Constraints on melting and magma production in the crust. Earth and Planetary Science Letters 86, 287-306.

Colchen, M., Le Fort, P. \& Pe^cher, A. (1986). Annapurna-Manaslu-Ganesh Himal. Paris: Centre National de la Recherche Scientifique, 136 pp.

Coleman, M. E. (1996). Orogen-parallel and orogen-perpendicular extension in the central Nepalese Himalayas. Geological Society of America Bulletin 108, 1594-1607.

Coleman, M. E. (1998). U-Pb constraints on Oligocene-Miocene deformation and anatexis within the central Himalaya, Marsyandi valley. American Journal of Science 298, 553-571.

Coleman, M. E. \& Hodges, K. V. (1998). Contrasting Oligocene and Miocene thermal histories from the hanging wall and footwall of the South Tibetan Detachment in the central Himalaya from 40Ar/39Ar thermochronology, Marsyandi valley, central Nepal. Tectonics 16, 726-740.

Copeland, P., Parrish, R. R. \& Harrison, T. M. (1988). Identification of inherited radiogenic $\mathrm{Pb}$ in monazite and its implications for $\mathrm{U}-\mathrm{Pb}$ systematics. Nature 333,760 763. 
Copeland, P., Harrison, T. M. \& Le Fort, P. (1990). Age and cooling history of the Manaslu granite: implications for Himalayan tectonics. Journal of Volcanology and Geothermal Research 44, 33-50.

Cruden, A. R. (1998). On the emplacement of tabular granites. Journal of the Geological Society, London 155, 853-862.

Davidson, C., Hollister, L. S. \& Schmid, S. M. (1992). Role of melt in the formation of a deep-crustal compressive shear zone: the Maclaren Glacier metamorphic belt, south central Alaska. Tectonics 11, 348-359.

Davidson, C., Schmid, S. M. \& Hollister, L. S. (1994). Role of melt during deformation in the deep crust. Terra Nova 3, 133-142.

Davidson, C., Grujic, D. E., Hollister, L. S. \& Schmid, S. M. (1997). Metamorphic reactions related to decompression and synkinematic intrusion of leucogranite, High Himalayan Crystallines, Bhutan. Journal of Metamorphic Geology 15, 593-612.

Deniel, C., Vidal, P., Fernandez, A., Le Fort, P. \& Peucat, J. J. (1987). Isotopic study of the Manaslu granite (Himalaya, Nepal): inferences on the age and source of Himalayan leucogranites. Contributions to Mineralogy and Petrology 96, 78-92.

Dèzes, P. J., Vannay, J. C., Steck, A., Bussy, F. \& Cosca, M. (1999). Synorogenic extension: quantitative constraints on the age and displacement of the Zanskar shear zone (northwest Himalaya). Geological Society of America Bulletin 111, 364-374.

Edmond, J. M. (1992). Himalayan tectonics, weathering processes and the strontium isotope record in marine limestones. Science 258, 1594-1597.

England, P. C. \& Thompson, A. B. (1984). Pressure-temperature-time paths of regional metamorphisms I: heat transfer during the evolution of regions of thickened continental crust. Journal of Petrology 25, 894-928.

England, P., Le Fort, P., Molnar, P. \& Pecher, A. (1992). Heat source for Tertiary metamorphism and anatexis in the Annapurna-Manaslu region, Central Nepal. Journal of Geophysical Research 97, 2107-2128.

Evans, D. J., Rowley, W. J., Chadwick, R. A. \& Millward, D. (1993). Seismic reflections from within the Lake District Batholith, Cumbria, Northern England. Journal of the Geological Society, London 150, 1043-1046.

France-Lanord, C. (1987). Chevauchement, metamorphisme et magmatisme en Himalaya du Ne'pal Central. Etude isotopique H, C, O. Ph.D. thesis, University of Nancy, 202 pp. 
France-Lanord, C., Sheppard, S. M. F. \& Lefort, P. (1988). Hydrogen and oxygen isotope variations in the High Himalaya Peraluminous Manaslu Leucogranite: evidence for heterogeneous sedimentary source. Geochimica et Cosmochimica Acta 52, 513526.

France-Lanord, C., Derry, L. \& Michard, A. (1993). Evolution of the Himalaya since Miocene time: isotopic and sedimentological evidence from the Bengal Fan. In: Treloar, P. J. \& Searle, M. P. (eds) Himalayan Tectonics. Geological Society, London, Special Publications 74, 603-621.

Furlong, K. P., Hanson, R. B. \& Bowers, J. R. (1991). Modeling thermal regimes. In: Kerrick, D. M. (ed.) Contact Metamorphism. Chelsea, MI: Mineralogical Society of America, pp. 437-498.

Glazner, A. F., Bartley, J. M., Coleman, D. S., Gray, W. \& Taylor, Z. T. (2004). Are plutons assembled over millions of years by amalgamation from small magma chambers? GSA Today 14, 4-11.

Grujic, D., Casey, M., Davidson, C., Hollister, L. S., Kundig, R., Pavlis, T. \& Schmid, S. M. (1996). Ductile extrusion of the Higher Himalayan Crystalline in Bhutan: evidence from quartz microfabrics. Tectonophysics 260, 21-43.

Guéguen, Y. \& Palciauskas, V. (1992). Introduction à la Physique des Roches.

Paris: Hermann, p. 299.

Guillot, S. (1993). Le granite du Manaslu (Ne'pal Central), marqueur de la subduction et de l'extension intracontinentales himalayenne. Ph.D. thesis, $97 \mathrm{pp}$.

Guillot, S. (1999). An overview of the metamorphic evolution in Central Nepal. Journal of Asian Earth Sciences 17, 713-725.

Guillot, S. \& Allemand, P. (2002). 2D thermal modelling of the early evolution of the Himalayan belt. Journal of Geodynamics 34, 77-98.

Guillot, S. \& Lefort, P. (1995). Geochemical constraints on the bimodal origin of High Himalayan Leucogranites. Lithos 35, 221-234.

Guillot, S., Pecher, A., Rochette, P. \& Le Fort, P. (1993). The emplacement of the Manaslu granite of central Nepal: field and magnetic susceptibility constraints. In: Treloar, P. J. \& Searle, M. P. (eds) Himalayan Tectonics. Geological Society, London, Special Publications 74, 413-428.

Guillot, S., Hodges, K. V., Le Fort, P. \& Pecher, A. (1994). New constraints on the age of the Manaslu leucogranite: evidence for episodic tectonic denudation in the central Himalayas. Geology 22, 559-562. 
Guillot, S., Le Fort, P., Pecher, A., Roy Barman, M. \& Aprahamian, J. (1995a). Contact metamorphism and depth of emplacement of the Manaslu granite (central Nepal): implications for Himalayan orogenesis. Tectonophysics 241, 99-119.

Guillot, S., Pecher, A. \& Le Fort, P. (1995b). Contrôles tectoniques et thermiques de la mise en place des leucogranites himalayens. Comptes Rendus de l'Académie des Sciences 320, 55-61.

Guillot, S., Garzanti, E., Baratoux, D., Marquer, D., Maheo, G. \& de Sigoyer, J. (2003). Reconstructing the total shortening history of the NW Himalaya. Geochemistry, Geophysics, Geosystems 4, Art. No. 1064

Haederle, M. \& Atherton, M. P. (2002). Shape and intrusion style of the Coastal Batholith, Peru. Tectonophysics 345, 17-28.

Harris, N. \& Inger, S. (1992). Geochemical characteristics of pelite-derived granites. Contributions to Mineralogy and Petrology 110, 46-56.

Harris, N. \& Massey, J. (1994). Decompression and anatexis of Himalayan metapelites. Tectonics 13, 1537-1546.

Harris, N., Ayres, M. \& Massey, J. (1995). Geochemistry of granitic melts produced during the incongruent melting of muscovite: implications for the extraction of Himalayan leucogranite magmas. Journal of Geophysical Research 100, 15767-15777.

Harris, N., Vance, D. \& Ayres, M. (2000). From sediment to granite: timescales of anatexis in the upper crust. Chemical Geology 162, 155-167.

Harris, N. B. W., Caddick, M., Kosler, J., Goswami, S., Vance, D. \& Tindle, A. G. (2004). The pressure-temperature-time path of migmatites from the Sikkim Himalaya. Journal of Metamorphic Geology 22, 249-264.

Harrison, T. M., Grove, M., Lovera, O. M. \& Catlos, E. J. (1998). A model for the origin of Himalayan anatexis and inverted metamorphism. Journal of Geophysical Research 103, 27017-27032.

Harrison, T. M., Grove, M., Lovera, O. M., Catlos, E. J., D’Andrea, J. \& McKeegan, K. (1999a). The origin of Himalayan anatexis and inverted metamorphism: models and constraints. Journal of Asian Earth Sciences 17, 755-772.

Harrison, T. M., Grove, M., McKeegan, K., Coath, C. D., Lovera, O. M. \& Le Fort, P. (1999b). Origin and episodic emplacement of the Manaslu Intrusive Complex, Central Himalaya. Journal of Petrology 40, 3-19.

Henry, P., Le Pichon, X. \& Goffe', B. (1997). Kinematic, thermal and petrological model of the Himalayas: constraints related to metamorphism within the underthrust Indian crust and topographic elevation. Tectonophysics 273, 31-56. 
Hodges, K. V., Parrish, R. R., Housh, T. B., Lux, D. R., Burchfiel, B. C., Royden, L. H. \& Chen, Z. (1992). Simultaneous Miocene extension and shortening in the Himalayan Orogen. Science 258, 1466-1470.

Hodges, K. V., Parrish, R. R. \& Searle, M. P. (1996). Tectonic evolution of the central Annapurna Range, Nepalese Himalayas. Tectonics 15, 1264-1291.

Hodges, K. V., Bowring, S., Davidek, K., Hawkins, D. \& Krol, M. (1998). Evidence for rapid displacement on Himalayan normal faults and the importance of tectonic denudation in the evolution of mountain ranges. Geology $26,483-486$.

Hodges, K. V., Hurtado, J. M. \& Whipple, K. X. (2001). Southward extrusion of Tibetan crust and its effects on Himalayan tectonics. Tectonics 20, 799-809.

Huerta, A. D., Royden, L. H. \& Hodges, K. V. (1999). The effects of accretion, erosion and radiogenic heat on the metamorphic evolution of collisional orogens. Metamorphic Geology 17, 349-366.

Huppert, H. E. \& Sparks, S. J. (1988). The generation of granitic magma by intrusion of basalt into continental crust. Journal of Petrology 29, 599-624.

Ingebritsen, S. E. \& Manning, C. E. (1999). Geological implications of a permeabilitydepth curve for the continental crust. Geology 27, 1107-1110.

Inger, S. \& Harris, N. (1992). Tectonothermal evolution of the High Himalayan crystalline sequence, Langtang Valley, northern Nepal. Journal of Metamorphic Geology 10, 439452.

Inger, S. \& Harris, N. (1993). Geochemical constraints on leucogranite magmatism in the Langtang valley, Nepal Himalaya. Journal of Petrology 34, 345-368.

Jaupart, C. \& Provost, A. (1985). Heat focusing, granite genesis and inverted metamorphic gradients in continental collision zones. Earth and Planetary Science Letters 73, 385-397.

Jellinek, A. M. \& Kerr, R. C. (1999). Mixing and compositional stratification produced by natural convection 2: applications to the differentiation of basaltic and silicic magma chambers and komatiite lava flows. Journal of Geophysical Research 104, 7203-7218.

Kohn, M. \& Parkinson, C. D. (2002). Petrologic case for Eocene slab breakoff during the Indo-Asian collision. Geology 30, 591-594.

Le Fort, P. (1975). Himalayas, the collided range: present knowledge of the continental arc. American Journal of Science 275A, 1-44.

Le Fort, P. (1981). Manaslu leucogranite: a collision signature of the Himalaya-a model for its genesis and emplacement. Journal of Geophysical Research 86, 10545-10568. 
Le Fort, P. (1986). Granites in the tectonic evolution of the Himalaya, Karakoram and southern Tibet. In: Coward, M. P. \& Ries, A. C. (eds) Collision Tectonics. Geological Society, London, Special Publications 19, 159-172.

Le Fort, P., Cuney, M., Deniel, C., France-Lanord, C., Sheppard, S. M. F., Upreti, B. N. \& Vidal, P. (1987). Crustal generation of the Himalayan leucogranites. Tectonophysics 134, 39-57.

Lejeune, A. M. \& Richet, P. (1995). Rheology of crystal-bearing silicate melts: an experimental study at high viscosities. Journal of Geophysical Research 100, 42154229.

Macfarlane, A. M. (1999). The metamorphic history of the crystalline rocks in the High Himalaya, Nepal: insights from thermobarometric data. In: Le Fort, P. \& Upreti, B. N. (eds) Geology of the Nepal Himalaya: Recent Advances. Oxford: Pergamon, pp. 741753.

Marsh, B. D. (1981). On the crystallinity, probability of occurrence, and rheology of lava and magma. Contributions to Mineralogy and Petrology 78, 85-98.

McCaffrey, K. J. W. \& Petford, N. (1997). Are granitic intrusions scale invariant? Journal of the Geological Society, London 154, 1-4.

Molnar, P., Wang-Pin, C. \& Padovani, E. (1983). Calculated temperatures in overthrust terrains and possible combinations of heat sources for the Tertiary granites in the Greater Himalaya. Journal of Geophysical Research 95, 4833-4856.

Montel, J. M. (1993). A model for monazite/melt equilibrium and application to the generation of granitic magmas. Chemical Geology 119, 127-146.

Murphy, M. A. \& Harrison, T. M. (1999). Relationship between leucogranites and the Qomolangma detachment in the Rongbuk valley, south Tibet. Geology 27, 831-834.

Nelson, K. D., Zhao, W. J., Brown, L. D., Kuo, J., Che, J. K., Liu, X. W., et al. (1996). Partially molten middle crust beneath southern Tibet: synthesis of project INDEPTH results. Science 274, 1684-1688.

Patino Douce, A. \& Harris, N. (1998). Experimental constraints on Himalayan anatexis. Journal of Petrology 39, 689-710.

Pecher, A. (1989). The metamorphism in the central Himalaya. Journal of Metamorphic Petrology 7, 31-41.

Pecher, A. (1991). The contact between the Higher Himalaya Crystallines and the Tibetan Sedimentary Series: Miocene largescale dextral shearing. Tectonics 10, 587598. 
Petford, N., Cruden, A. R., McCaffrey, K. J. W. \& Vigneresse, J.-L. (2000). Granite magma formation, transport and emplacement in the Earth's crust. Nature 408, 669673.

Pham, V. N., Boyer, D., Therme, P., Yuang, X. C., Li, L. \& Jin, G. Y. (1986). Partial melting zones in the crust in southern Tibet from magnetotelluric results. Nature 311, 310-314.

Pichavant, M., Kontak, D. J., Briqueu, L., Valencia Herrera, J. \& Clark, A. H. (1988). The Miocene-Pliocene Macusani volcanics, SE Peru. II. Geochemistry and origin of a felsic peraluminous magma. Contributions to Mineralogy and Petrology 100, 325-338.

Pinet, C. \& Jaupart, C. (1987). A thermal model for the distribution in space and time of the Himalayan granites. Earth and Planetary Science Letters 84, 87-99.

Raia, F. \& Spera, F. J. (1997). Simulation for the growth and differentiation of continental crust. Journal of Geophysical Research 102, 22629-22648.

Raymo, M. E. \& Ruddiman, W. F. (1992). Tectonic forcing of late Cenozoic climate. Nature 359, 117-122.

Robertson, E. C. (1988). Thermal properties of rocks. US Geological Survey Open File Report 88-441, 106 pp.

Roscoe, R. (1952). The viscosity of suspensions of rigid spheres. British Journal of Applied Physics 3, 267-269.

Rowley, D. B. (1996). Age of initiation of collision between India and Asia: a review of stratigraphic data. Earth and Planetary Science Letters 145, 1-13.

Roy, R. F., Blackwel, D. D. \& Birch, F. (1968). Heat generation of plutonic rocks and continental heat flow provinces. Earth and Planetary Science Letters 5, 1-12.

Royden, L. H. \& Burchfiel, B. C. (1985). Thin-skinned N-S extension within the convergent Himalayan region: gravitational collapse of a Miocene topographic front. In: Coward, M. P., Dewey, J. F. \& Hancock, P. L. (eds) Continental Extensional Tectonics. Oxford: Blackwell, pp. 611-619.

Scaillet, B., Pecher, A., Rochette, P. \& Champenois, M. (1995a). The Gangotri granite (Gahrwal Himalaya): laccolithic emplacement in an extending collisional belt. Journal of Geophysical Research 100, 585-607.

Scaillet, B., Pichavant, M. \& Roux, J. (1995b). Experimental crystallization of leucogranite magmas. Journal of Petrology 36, 663-705. 
Scaillet, B., Holtz, F., Pichavant, M. \& Schmidt, M. (1996). Viscosity of Himalayan leucogranites: implications for mechanisms of granitic magma ascent. Journal of Geophysical Research 101, 27691-27699.

Scaillet, B., Holtz, F. \& Pichavant, M. (1997). Rheological properties of granitic magmas in their crystallization range. In: Bouchez, J. L., Hutton, D. \& Stephens, W. E. (eds) Granites: From Segregation of Melt to Emplacement Fabrics. Boston, MA: Kluwer Academic, pp. 11-29.

Searle, M. P. (1999). Emplacement of Himalayan leucogranites by magma injection along giant sill complexes: examples from the Cho Oyu, Gyachung Kang and Everest leucogranites (Nepal Himalaya). Journal of Asian Earth Sciences 17, 773-783.

Searle, M. P. \& Godin, L. (2003). The South Tibetan Detachment and the Manaslu Leucogranite: a structural reinterpretation and restoration of the Annapurna-Manaslu Himalaya, Nepal. Journal of Geology 111, 505-523.

Searle, M. P., Metcalfe, R. P., Rex, A. J. \& Norry, M. J. (1993). Field relations, petrogenesis and emplacement of the Bhagirathi leucogranite, Garhwal Himalaya. In: Treloar, P. J. \& Searle, M. P. (eds) Himalayan Tectonics. Geological Society, London, Special Publications 19, 429-444.

Searle, M. P., Parrish, R. R., Hodges, K. V., Hurford, A., Ayres, M. W. \& Whitehouse, M. J. (1997). Shisha Pangma leucogranite, South Tibetan Himalaya: field relations, geochemistry, age, origin and emplacement. Journal of Geology 105, 295-317.

Searle, M. P., Simpson, R. L., Law, R. D., Parrish, R. R. \& Waters, D. J. (2003). The structural geometry, metamorphic and magmatic evolution of the Everest massif, High Himalaya of Nepal-South Tibet. Journal of the Geological Society, London 160, 345366.

Shmonov,V. M., Vitiovtova, V. M., Zharikov, A. V.\&Grafchikov, A. A. (2003). Permeability of the continental crust: implications of experimental data. Journal of Geochemical Exploration 78-9, 697-699.

Sparks, R. S. J., Huppert, H. E. \& Turner, J. S. (1984). The fluiddynamics of evolving magma chambers. Philosophical Transactions of the Royal Society of London, Series A-Mathematical Physical and Engineering Sciences 310, 511 et seq.

Turcotte, D. L. \& Schubert, G. (1982). Geodynamics. New York: John Wiley, 450 pp.

Vannay, J. C. \& Grasemann, B. (2001). Himalayan inverted metamorphism and synconvergence extension as a consequence of a general shear extrusion. Geological Magazine 138, 253-276. 
Vidal, P., Cocherie, A. \& Le Fort, P. (1982). Geochemical investigations of the origin of the Manaslu leucogranite (Himalaya, Nepal). Geochimica et Cosmochimica Acta 46, 2279-2292.

Visona, D. \& Lombardo, B. (2002). Two-mica and tourmaline leucogranites from the Everest-Makalu region (Nepal-Tibet): Himalayan leucogranite genesis by isobaric heating? Lithos 62, 125-150.

Walker, J. D., Martin, M. W., Bowring, S. A., Searle, M. P., Waters, D. J. \& Hodges, K. V. (1999). Metamorphism, melting, and extension: age constraints from the High Himalayan Slab of southeast Zanskar and northwest Lahaul. Journal of Geology 107, 473-495.

Wenk, H. R. \& Wenk, E. (1969). Physical constant of Alpine rocks (density, porosity, specific heat, thermal diffusivity and conductivity). Schweizerische Mineralogische und Petrographische Mitteilungen 49, 343-358.

Wiebe, R. A. \& Collins, W. J. (1998). Depositional features and stratigraphic sections in granitic plutons: implications for the emplacement and crystallization of granitic magma. Journal of Structural Geology 20, 1273-1289.

Wu, C., Nelson, K. D., Wortman, G., Samson, S. D., Yue, Y., Li, J., Kidd, W. S. F. \& Edwards, M. A. (1998). Yadong cross structure and South Tibetan Detachment in the east central Himalaya $\left(89^{\circ}-90^{\circ} \mathrm{E}\right)$. Tectonics $17,28-45$. 